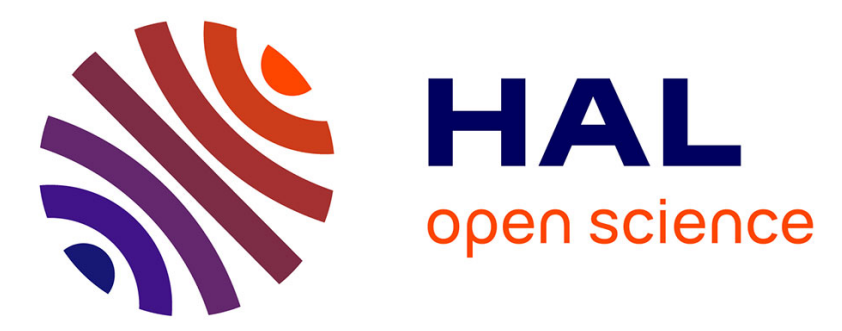

\title{
Introduced ants (Hymenoptera: Formicidae) of mainland France and Belgium, with a focus on greenhouses
}

Rumsais Blatrix, Théotime Colin, Philippe Wegnez, Christophe Galkowski, Philippe Geniez

\section{- To cite this version:}

Rumsais Blatrix, Théotime Colin, Philippe Wegnez, Christophe Galkowski, Philippe Geniez. Introduced ants (Hymenoptera: Formicidae) of mainland France and Belgium, with a focus on greenhouses. Annales de la Société Entomologique de France, 2018, 54 (4), pp.293-308. 10.1080/00379271.2018.1490927 . hal-02109530

\section{HAL Id: hal-02109530 \\ https://hal.science/hal-02109530}

Submitted on 14 Oct 2019

HAL is a multi-disciplinary open access archive for the deposit and dissemination of scientific research documents, whether they are published or not. The documents may come from teaching and research institutions in France or abroad, or from public or private research centers.
L'archive ouverte pluridisciplinaire HAL, est destinée au dépôt et à la diffusion de documents scientifiques de niveau recherche, publiés ou non, émanant des établissements d'enseignement et de recherche français ou étrangers, des laboratoires publics ou privés. 
Introduced ants (Hymenoptera, Formicidae) of mainland France and Belgium, with a focus on greenhouses

\section{Les fourmis (Hymenoptera, Formicidae) introduites en France métropolitaine et en Belgique, avec un focus sur les serres}

Rumsaïs Blatrix ${ }^{1,2}$, Théotime Colin ${ }^{2,3}$, Philippe Wegnez ${ }^{2,4,5}$, Christophe Galkowski ${ }^{2,6}$, Philippe Geniez ${ }^{7}$

${ }^{1}$ CEFE, CNRS, University of Montpellier, University Paul Valéry Montpellier 3, EPHE, IRD, 1919 route de Mende, 34293 Montpellier, France.

${ }^{2}$ Antarea (www.antarea.fr), association for the study and mapping of the ants of France.

${ }^{3}$ Biology Department, Macquarie University, Sydney, Australia.

${ }^{4}$ Rue de la Grotte 23, 4651 Herve, Belgium.

${ }^{5}$ Walbru (www.fourmiswalbru.com), french-speaking Belgian association for the inventory of ants of Wallonie and Brussels.

${ }^{6} 104$ route de Mounic, 33160 Saint-Aubin-de-Médoc, France.

${ }^{7}$ EPHE, PSL Research University, CNRS, UM, SupAgro, IRD, INRA, UMR 5175 CEFE, 34293 Montpellier, France.

Corresponding author:

Rumsaïs Blatrix

Email : rumsais.blatrix@cefe.cnrs.fr 


\section{Abstract}

The monitoring of introduced species is becoming more important as global trade intensifies. Although ants make up a larger proportion of species on the list of the most invasive species in the world compared with other groups, little is known about the occurrence of those introduced in France, especially inside heated buildings. Here we review the literature available for mainland France and Belgium and report the results of a survey conducted with the help of tropical building managers between 2014 and 2016. We report for the first time in France the presence of Technomyrmex vitiensis and Plagiolepis alluaudi in multiple greenhouses. Technomyrmex difficilis was also found in one greenhouse for the first time in Europe. The diversity of introduced ants in greenhouses is very low, and these buildings are most often dominated by one or two species. We compared the most recent data and those collected throughout the $20^{\text {th }}$ century, and showed that ant communities have changed substantially. Greenhouses could be responsible for the introduction of invasive species because they regularly import exotic plants, but we found no evidence that the three species of invasive ants present outdoors in France were introduced from greenhouses, where they rarely occur. We also report that introduced ants are pests in greenhouses because they disperse scale insects and kill biological control agents. The suppression of these ants could ease the maintenance of plants inside greenhouses.

Keywords: Formicidae, introduced species, tropical greenhouses, biological invasions 


\section{Résumé}

Avec l'intensification des échanges internationaux, la veille sur les espèces introduites devient de plus en plus pertinente. Les fourmis représentent une proportion importante des espèces considérées comme les plus envahissantes, et pourtant la littérature sur l'occurrence de fourmis introduites en France est peu abondante et peu détaillée, en particulier en ce qui concerne les bâtiments chauffés. Cet article dresse le bilan des connaissances sur ce sujet pour la France métropolitaine et la Belgique, en se basant sur les données de la littérature et d'une enquête menée auprès des gestionnaires d'espaces tropicalisés entre 2014 et 2016. Technomyrmex vitiensis et Plagiolepis alluaudi ont été détectées pour la première fois dans plusieurs serres de France. De même, Technomyrmex difficilis a été trouvée dans une serre pour la première fois en Europe. Le cortège d'espèces introduites présentes dans les serres tropicales est peu diversifié, et souvent dominé par une ou deux espèces. En comparant les données actuelles avec celles du début du XXème siècle, il apparaît que la composition de ce cortège s'est modifiée. Les espaces tropicalisés pourraient être responsables de l'introduction d'espèces envahissantes car ils importent régulièrement des plantes exotiques, mais les trois espèces de fourmis introduites et envahissantes présentes en extérieur n'ont visiblement pas été introduites par ce biais et sont peu représentées dans les serres. Cependant, les fourmis introduites nuisent aux plantes des serres tropicales en protégeant et propageant les cochenilles, et parfois en détruisant les auxiliaires de lutte biologique. La mise en place de moyens de lutte contre ces fourmis pourrait faciliter le maintien de certaines espèces de plantes tropicales en serre.

Mots clés : Formicidae, espèce introduite, serre tropicale, invasions biologiques. 


\section{Introduction}

Intensifying global trade has increased the rate of exotic species introduction events (Bertelsmeier et al. 2017), especially for species originating from tropical habitats (Westphal et al. 2008). In more temperate climate conditions, most of these species cannot survive in their area of introduction and are only intercepted at ports of entry (Boer and Vierbergen 2008), but the few that survive and settle can rapidly become invasive. Tropical species are usually constrained by local climates, but infrastructures that are heated all year round provide shelter to many introduced species (e.g. Bauer et al. 2015). Comparing the species that can only survive in heated buildings with the invasive species living outdoor can help determine which traits are associated with invasiveness.

Nineteen ant species (Hymenoptera: Formicidae) are listed in the Global Invasive Species Database of the International Union for the Conservation of Nature (Global Invasive Species Database <www.iucngisd.org/gisd/>, accessed on 11.IX.2017), five of which are in the top one hundred world's worst invasive alien species list. Some members of the Formicidae family are experts at colonising new habitats and are well-adapted to human-mediated dispersion. In France, outdoor invasive species are well-studied and monitored by the public science project AntArea (www.antarea.fr), which maps all the ants of France living outdoors. However, ants introduced to the inside of buildings are poorly studied and there are no recent surveys available to this day. Rasplus et al. (2010) provide a list of Hymenoptera alien to Europe and list 16 ant species alien to France, which is likely an underestimation. The little data 
available are only rarely linked to a specific location or to a museum specimen. To fill this gap, we reviewed the literature and conducted a survey with the help of tropical building managers. We report this review here to assist those working in buildings with climate conditions similar to those in tropical environments to better know the introduced ant species that they may encounter.

Although plant trade is more likely to be the main point of entry for exotic ant species, exotic ants are rarely observed in plant shops (authors personal observations), possibly because of the high plant turnover or insecticide treatments. We focused on public and private greenhouses open to the public because plants are often left undisturbed, allowing ant colonies to develop, which facilitates their detection. Greenhouses import a considerable amount of plants from the Neotropics, a region of the world considered as an important source of introduced ant species (Miravete et al. 2014). Moreover, greenhouses are considered historical entry points for exotic ant species (e.g. Boer \& Vierbergen 2008).

\section{Materials and Methods}

We considered data from: 1) the literature and personal observations, when species determination was verified by inspecting specimens (including those in museums) or judged unambiguous because the species has characteristic features that differentiate it clearly from other species (for example, the very particular color pattern of Tapinoma melanocephalum), and 2) data collected in greenhouses and tropical buildings in France and Belgium between 2014 and 2016. During this period, 
we solicited 26 organizations managing tropical greenhouses and obtained or collected samples from 11 of them. We also asked the employees of these structures to report any damage caused by the ants. We decided to focus on greenhouses because introduced ant species are particularly abundant and easy to detect in these structures. Species identification followed recent taxonomic work and specific keys (e.g. Bolton 2007, Bolton \& Fischer 2011, Seifert 2013, Sarnat et al. 2015), and comparison with original descriptions and type specimens (we used high resolution images of type specimens provided by the AntWeb project, available from http://www.antweb.org). For most of the new records presented in this study, identification relied on tens of workers. Specimens are kept in the personal collections of the authors.

We classified the species based on Bolton et al. (2006) (We did not consider records of ants intercepted at entry points):

- Temporarily introduced ants: non-native ants that are found at the place of first record, and do not spread to other areas, forming populations that eventually go extinct.

- Maintained introduced ants: non-native ant populations for which the survival depends directly on human buildings, and that have spread to areas outside the place of first record. These species do not form stable populations outdoors. - Permanently introduced ants: non-native ant species forming permanent populations outdoors. They can also be found indoors. 
Categorization of ant species depends on the spatial extent and time period considered. Categorization in this paper was defined for the beginning of the $21^{\text {st }}$ century in France and Belgium (i.e. the same species may belong to a different category in another country). We decided not to report records of indigenous species, of species intercepted only at entry points, and of species that are indigenous to parts of France and Belgium but introduced in other areas, for example, Tapinoma magnum, Tapinoma darioi and Tetramorium immigrans. The first two species share traits with invasive species in many urban areas where they have been recently introduced (Seifert et al. 2017), but there is some uncertainty regarding their origin and they may have been introduced from the French Mediterranean coast. The third species has most likely been introduced from Anatolia or Caucasia, but the date and place of introduction to Western Europe are unknown (Wagner et al. 2017).

\section{Results}

We recorded 30 ant species that are either permanently introduced (three species), maintained introduced (15 species) or temporarily introduced (12 species) in mainland France or Belgium (Table 1). All occurrences of introduced species reported in this article are available online in the supplementary material section (Table S1).

List of records of the permanently introduced species 
The following three species have established permanent and stable populations outdoor in France and/or Belgium.

Lasius neglectus Van Loon, Boomsma \& Andrasfalvy, 1990 (sub-family Formicinae)

BELGIUM - Outdoor, in Ghent [51 $\left.2.4^{\prime} \mathrm{N} 3^{\circ} 43.2^{\prime} \mathrm{E}\right]$ since 1978 at least (Dekoninck et al. 2002), and in Flémalle [50³6.0'N 5²6.4'E], 2008, D. Ignace (Dekoninck et al. 2010). Indoor in the botanical garden of the University of Ghent $\left[51^{\circ} 2.10^{\prime} \mathrm{N}\right.$ $\left.3^{\circ} 43.38 ' E\right]$ (Dekoninck et al. 2010).

FRANCE - Outdoor in the Mediterranean area, in Corsica, on the Atlantic coast, along the Loire and Rhone rivers, more rarely in other areas (Fig. 2a). It can be found inside buildings, which is also the case for several indigenous species of Lasius, and has been found in the dry greenhouse of the botanical garden of Nantes [47 $\left.13.26^{\prime} \mathrm{N} 1^{\circ} 32.64^{\prime} \mathrm{W}\right]$ (Gouraud 2015) and in private houses in Saint-Désirat (Ardèche) $\left[45^{\circ} 15^{\prime} \mathrm{N} 4^{\circ} 46.8^{\prime} \mathrm{E}\right]$.

Linepithema humile (Mayr, 1868) (sub-family Dolichoderinae) known as the « Argentine ant »

BELGIUM - Greenhouses of the botanical gardens of Brussels [5051.30'N

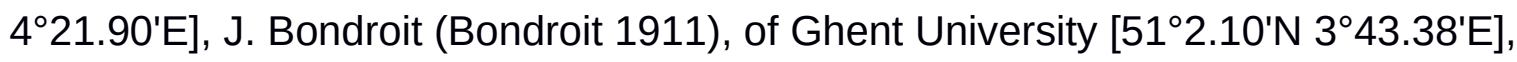
summer 2004, W. Dekoninck (Dekoninck, Maelfait, et al. 2006), and of Meise [5055.50'N 4²19.80'E], 18.IV.2016, P. Wegnez.

FRANCE - Outdoor it is mostly found along the Mediterranean coastline including Corsica, and is seldom found in the South-West of France (Fig. 1b). It can also 
survive in buildings like in the Paul Sabatier University in Toulouse $\left[43^{\circ} 33.516^{\prime} \mathrm{N}\right.$ $\left.1^{\circ} 28.278^{\prime} \mathrm{E}\right], \mathrm{T}$. Colin and A. Dejean, or in the Eyzies biological station [44 ${ }^{\circ} 56.4^{\prime} \mathrm{N}$ $\left.1^{\circ} 1.2^{\prime} E\right]$, B. Darchen (Galkowski 2008), the tropical greenhouses of the Jardin des Plantes de Paris [48 $\left.{ }^{\circ} 50.586 ' N 2^{\circ} 21.432 ' E\right]$, C. Galkowski (Galkowski 2008), and of Bordeaux [4450.658'N 0³3.522'W], XI.2007, C. Galkowski (Galkowski 2008), the Amazonian greenhouse of the Lunaret zoo of Montpellier [43 $\left.{ }^{\circ} 38.358^{\prime} \mathrm{N} 3^{\circ} 52.440^{\prime} \mathrm{E}\right]$, 07.II.2014, R. Blatrix, and the tropical greenhouse of the botanical garden of Tours [47²3.364'N 040.020'E], 13.III.2015, R. Cézé et M. Froger.

Monomorium carbonarium (Smith, 1858) (sub-family Myrmicinae)

FRANCE - On the Atlantic coast, from Pyrénées-Atlantique to Morbihan, and more rarely away from the coast (Fig. 1c). This species is known from France since 1970 (Yeux island, J. Casevitz-Weulersse).

List of records of the maintained introduced species found in mainland France and Belgium

The following species, except for Hypoponera punctatissima, can only survive indoors in France and Belgium.

Brachymyrmex sp. (sub-family Formicinae)

BELGIUM - Tropical greenhouses of the botanical garden of Brussels [5051.30' N $\left.4^{\circ} 21.90 ' E\right], 1908, \mathrm{~J}$. Bondroit (Bondroit 1911), identified by Bondroit as Brachymyrmex heeri Forel, 1874. 
FRANCE - Large greenhouse of the Jardin des Plantes de Paris $\left[48^{\circ} 50.586^{\prime} \mathrm{N}\right.$ $\left.2^{\circ} 21.432^{\prime} E\right], 05 . I V .2016$, R. Blatrix et P. Wegnez. The specimens found are morphologically similar to the ones from the island of la Réunion, France, where Brachymyrmex cordemoyi Forel, 1895 was first described, and might belong to this species.

Hypoponera ergatandria (Forel, 1983) (sub-family Ponerinae)

BELGIUM - Tropical greenhouse of the botanical garden of Brussels [5051.30' $\mathrm{N}$ $\left.4^{\circ} 21.90 ' E\right]$, XI.1909, J. Bondroit (Bondroit 1911). Heated buildings in Maarkedal [5048'N 336'E], 10.XI.1995 and winter 1996, P. Grootaert (Dekoninck, Maelfait, et al. 2006). Tropical greenhouse of the botanical garden of Meise [5055.50' $\mathrm{N}$ $\left.4^{\circ} 19.80 ' E\right], 18 . I V .2016$, P. Wegnez. Tropical greenhouse of the park Pairi Daiza in Brugelette [50³5.70'N 351.78'E], 28.IV.2016, P. Wegnez. Tropical greenhouse of the plant observatorium Sart Tilman in Liège [50³4.692' N 5³5.292'E], V.2016, P. Wegnez. Tropical greenhouse of the botanical garden of Liège $\left[50^{\circ} 38.10^{\prime} \mathrm{N}\right.$ 5³3.72'E], 2012, P. Wegnez.

FRANCE - Large tropical greenhouse of the Jardin des Plantes de Paris and associated buildings [48 $\left.50.58^{\prime} \mathrm{N} 2^{\circ} 21.42^{\prime} \mathrm{E}\right]$, J. Bondroit (Bernard 1968); 05.IV.2016, R. Blatrix et P. Wegnez. Acclimatisation and Amazonian greenhouses of the Lunaret zoo of Montpellier [4338.346'N 352.620'E], 05.III.2015, 07.IX.2017, R. Blatrix. Tropical greenhouse of the botanical garden of Metz [496.264' $\left.\mathrm{N} 6^{\circ} 9.642^{\prime} \mathrm{E}\right]$, VI.2015, A. Rotini. Zoo of the Jardin des Plantes de Paris [4850.70'N 2²1.54'E], 5.IV.2016, R. Blatrix et P. Wegnez. Tropical greenhouse of Auteuil, Paris 
[48 $\left.50.778^{\prime} \mathrm{N} 2^{\circ} 15.126^{\prime} \mathrm{E}\right], \mathrm{V} .2016, \mathrm{~T}$. Colin. Tropical greenhouse of the botanical garden of Sens [48 $\left.11.742^{\prime} N 3^{\circ} 16.812^{\prime} E\right], 08 . V .2016$, J. Ho-Huu.

Hypoponera punctatissima (Roger, 1859) (sub-family Ponerinae)

BELGIQUE - Swarm in an urban area, Liège [50³7.8'N 5³4.2'E], summer 1990, P. Wegnez (Wegnez et al. 2012). Brussels [5050.28'N 4²2.20'E], 16.VIII.1994 (Seifert 2013). Leuven [5052.8'N 442.0'E], 10.VII.1998 (Seifert 2013). Limburg [5046.2' N $\left.5^{\circ} 15.6^{\prime} \mathrm{E}\right], 16$.VIII.1998 (Seifert 2013). Swarm in a building, Herve [50³8.4' $\mathrm{N}$ 547.4'E], summer 2007, P. Wegnez (Wegnez et al. 2012). Outdoor on a spoil tip, Charleroi [50²3.4' $\left.4^{\circ} 27^{\prime} \mathrm{E}\right]$ (Wegnez et al. 2012). Outdoor on a spoil tip, Liège [5040.8'N 5³4.2'E] (Wegnez et al. 2012).

FRANCE - Saint-Jeannet [ $\left.43^{\circ} 42^{\prime} N 7^{\circ} 6^{\prime} E\right]$, Hervé (Bernard 1968). Saint-Rémy-la-

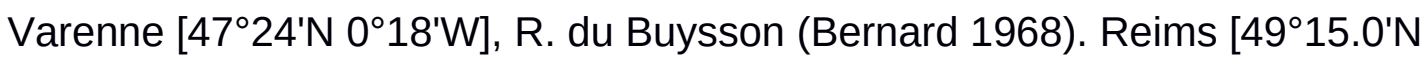
4¹.8'E], 24.VI.1934 et 18.VII.1934 (Seifert 2013). Swarm, Toulon [436'N 554'E],

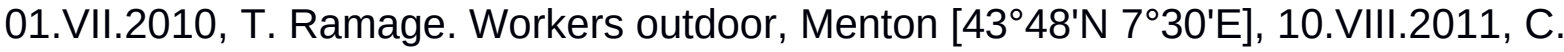
Galkowski. Workers, Sillé-le-Guillaume [48 $\left.12^{\prime} \mathrm{N} 0^{\circ} 6^{\prime} \mathrm{W}\right], 22 . I X .2014$, F. Noel. Swarm, Béthisy-Saint-Martin [49²18'N 248'E], 25.VI.2015, 13-14.IX.2016, L. Colindre. Workers outdoor, Marchiennes [50²4'N 318'E], 24.VII.2015, B. Derolez. Swarm, Desvres [5042'N 148'E], 25.IV.2016, A. Marcy. Swarm, Saint-Germain

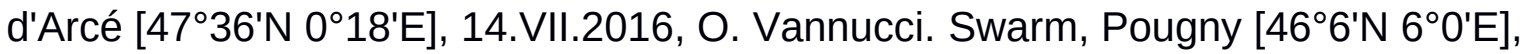
04.VI.2017, C. Lebas. Sollacaro (Corse) [41444.718'N 852.182'E] (K. Gomez, personal communication).

Monomorium pharaonis (Linnaeus, 1758) (sub-family Myrmicinae) 
BELGIQUE - Mentioned with no precise location (Dekoninck, Maelfait, et al. 2006). Tropical greenhouse of the botanical garden of Liège [50 $\left.38.10^{\prime} \mathrm{N} 5^{\circ} 33.72^{\prime} \mathrm{E}\right], 2012$, $\mathrm{P}$. Wegnez. Different houses in Liège $\left[50^{\circ} 36^{\prime} \mathrm{N} 5^{\circ} 36^{\prime} \mathrm{E}\right], \mathrm{P}$. Wegnez. FRANCE - Houses in Paris [48 $\left.48^{\prime} \mathrm{N} 2^{\circ} 18^{\prime} \mathrm{E}\right]$ (Nylander 1856; André 1883; Bernard

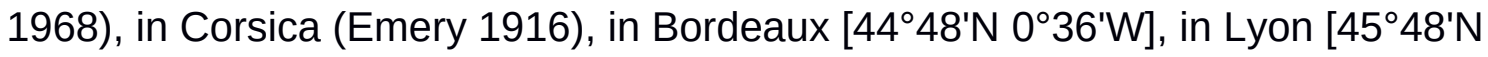

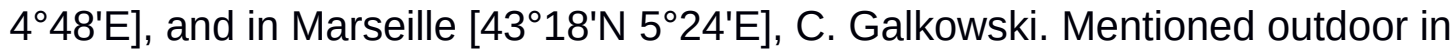
Corsica (Bondroit 1918); Bonifacio [4123.4'N 99.6'E], Ferton (Bernard 1968).

Nylanderia vividula (Nylander, 1846) (sub-family Formicinae)

FRANCE - Reported to be inside heated greenhouses with no precise location (Bernard 1968).

Paratrechina longicornis (Latreille, 1802) (sub-family Formicinae)

BELGIQUE - Tropical aquatic park of De Haan [51¹7.034'N 3³.810'E], 11.XI.2010, W. Dekoninck and D. Brouckaert (Dekoninck \& Brouckaert 2011).

FRANCE - Tropical greenhouses in Paris [48 ${ }^{\circ} 48^{\prime} \mathrm{N} 2^{\circ} 18^{\prime} \mathrm{E}$ ] (Nylander 1856; Emery 1878; André 1883; Emery 1910; Bondroit 1918).

Pheidole anastasii Emery, 1896 (sub-family Myrmicinae)

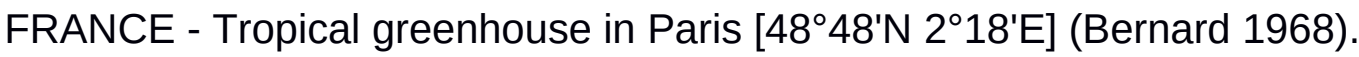

Pheidole bilimeki Mayr, 1870 (sub-family Myrmicinae)

BELGIQUE - Tropical greenhouse of the botanical garden of Brussels [5051.30'N $\left.4^{\circ} 21.90 ' E\right]$, J. Bondroit (Bondroit 1911). 


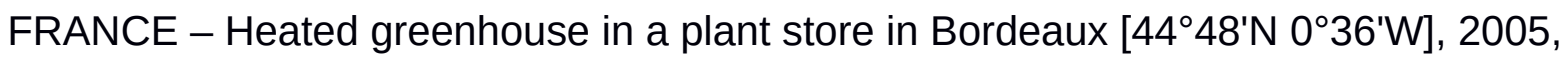
C. Galkowski (Casevitz-Weulersse \& Galkowski 2009).

Pheidole megacephala (Fabricius, 1793) (sub-family Myrmicinae)

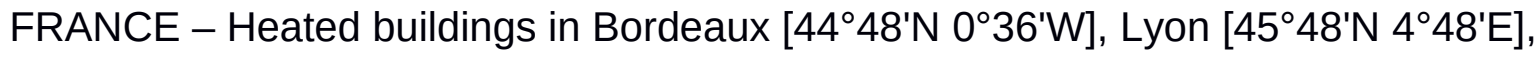
and Paris [48 $48^{\prime} \mathrm{N} 2^{\circ} 18^{\prime} \mathrm{E}$ ] (Bernard 1968). Large tropical greenhouse of the Jardin des Plantes de Paris [4850.586'N 2²1.432'E], 5.IV.2016, R. Blatrix et P. Wegnez.

Plagiolepis alluaudi Emery, 1894 (sub-family Formicinae)

BELGIQUE - Tropical greenhouse of the park Pairi Daiza à Brugelette [50³5.70'N $\left.3^{\circ} 51.78 ' E\right], 28 . I V .2016$, P. Wegnez. Tropical greenhouse of the plant observatorium Sart Tilman in Liège [50³4.692'N 5³5.292'E], V.2016, P. Wegnez.

FRANCE - Large tropical greenhouse of the Jardin des Plantes de Paris and associated buildings [4850.58'N 2²1.42'E], 5.IV.2016, R. Blatrix et P. Wegnez. Tropical greenhouse of the botanical garden Henri Gaussen of Paul Sabatier University in Toulouse [43³5.6292'N 1²6.9628'E], VI.2016, N. Séjalon-Delmas.

Tapinoma melanocephalum (Fabricius, 1793) (sub-family Dolichoderinae) BELGIQUE - House in Liège [50³7.716'N 5³4.908'E], 7.II.2006, 22.V.2006, P. Wegnez (Dekoninck, Wegnez, et al. 2006). Tropical aquatic park of Oostduinkerke [51 $\left.{ }^{\circ} 7.92^{\prime} \mathrm{N} 2^{\circ} 42.72^{\prime} E\right], 25 . I V .2011$, W. Dekoninck et D. Brouckaert (Dekoninck \& Brouckaert 2011).

FRANCE - Tropical greenhouse of Auteuil, Paris [4850.778'N 2¹5.126'E], 2002 (Casevitz-Weulersse \& Galkowski 2009); VII.2008, H. Darras; V.2016, T. Colin. 
Tropical greenhouse of the botanical garden of Strasbourg University $\left[48^{\circ} 35.052^{\prime} \mathrm{N}\right.$ 745.870'E], 2003, H. Callot (Hugel et al. 2003); 5.II.2015, H. Callot. Hotel in Paris [48 $\left.50.70^{\prime} N 2^{\circ} 17.64 ' E\right], 2015$, B. Kaufmann. Museum of Natural History of Paris, Laboratory of herpetology [48 $\left.50.761^{\prime} \mathrm{N} 2^{\circ} 21.597 ' \mathrm{E}\right], 16 . \mathrm{II} .2015$, P. Geniez (Blatrix \& Geniez 2015). Tropical greenhouse of the arboretum of Chevreloup, Rocquencourt

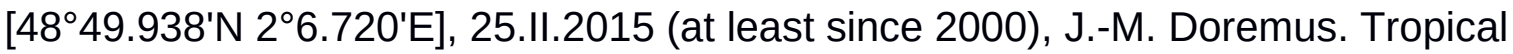
greenhouse of the Museum of Natural History of Grenoble [45²1.25'N 544.124'E], 10.III.2015, S. Poletti. Tropical greenhouse of the botanical garden of Lyon [4546.398'N 451.288'E], 7.V.2015, J.-M. Tete. Tropical greenhouse of the botanical garden and conservatorium of Nancy [48³9.756' $\left.\mathrm{N} 6^{\circ} 9.234^{\prime} \mathrm{E}\right], 24 . \mathrm{VI} .2015, \mathrm{~L}$. Gardeux et A. Bour. Tropical greenhouse of the botanical garden of Metz [49⒍264'N 69.642'E], VI.2015, A. Rotini. Zoo of the Jardin des Plantes de Paris $\left[48^{\circ} 50.70^{\prime} \mathrm{N} 2^{\circ} 21.54^{\prime} \mathrm{E}\right], 5 . I V .2016$, R. Blatrix et P. Wegnez.

Technomyrmex difficilis Forel, 1892 (sub-family Dolichoderinae) FRANCE - Tropical greenhouse of the botanical garden of Lyon [45 $46.398^{\prime} \mathrm{N}$ 451.288'E], 16.IV.2015, P. Avoscan et A. Donzet.

Technomyrmex vitiensis Mann, 1921 (sub-family Dolichoderinae) BELGIQUE - Tropical greenhouse of the park Pairi Daiza in Brugelette [50³5.70'N 351.78'E], 17.I.2008, P. Wegnez et D. Ignace (Dekoninck et al. 2010); 28.IV.2016, P. Wegnez. Tropical greenhouse of the botanical garden Ghent University

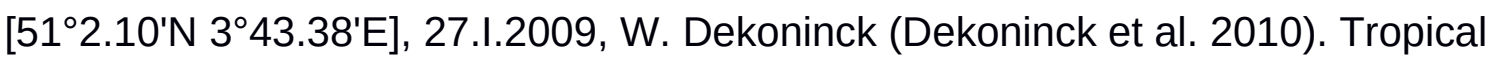




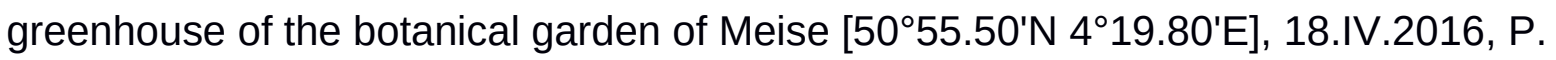
Wegnez.

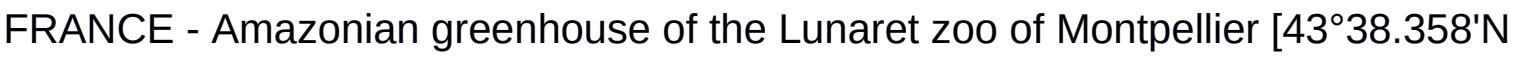
$\left.3^{\circ} 52.440 ' E\right]$, 7.II.2014, 5.III.2015, 7.IX.2017, R. Blatrix. Acclimatisation greenhouse

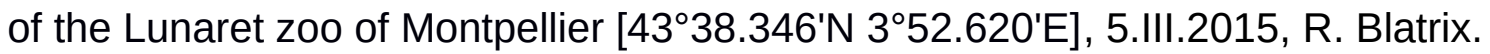
Tropical greenhouse of the Naturospace of Honfleur [49²5.536' $\left.\mathrm{N} 0^{\circ} 13.764^{\prime} \mathrm{E}\right]$, 24.III.2015, B. Mery. Tropical greenhouse of the botanical garden and conservatorium of Nancy [48 $\left.39.756^{\prime} \mathrm{N} 6^{\circ} 9.234^{\prime} \mathrm{E}\right], 24 . \mathrm{VI} .2015$, L. Gardeux et A. Bour. Tropical greenhouse of Auteuil, Paris [4850.778'N 2¹5.126'E], V.2016, T. Colin.

Tetramorium bicarinatum (Nylander, 1846) (sub-family Myrmicinae) BELGIQUE - Building in Herstal [5040.2'N 5³7.8'E], V.2004, P. Wegnez (Dekoninck, Maelfait, et al. 2006). Tropical greenhouse of the park Pairi Daiza in Brugelette [50³5.70'N 351.78'E], 28.IV.2016, P. Wegnez.

FRANCE - Mentioned inside greenhouses without any details (Bondroit 1918; Bernard 1968).

Tetramorium groupe simillimum (sub-family Myrmicinae) FRANCE - Mentioned inside greenhouses without any details (Bernard 1968).

List of records of the temporarily introduced species 
Aphaenogaster gemella (Roger, 1862) (sub-family Myrmicinae). Outdoor in Saintes-Maries-de-la-mer $\left[43^{\circ} 27.0^{\prime} \mathrm{N} 4^{\circ} 25.8^{\prime} \mathrm{E}\right]$, in Camargue and in Villefranche-sur-

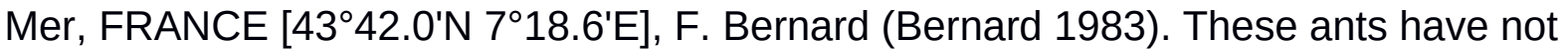
been found ever since.

Camponotus barbaricus Emery, 1905 (sub-family Formicinae). Outdoor in Draguignan, FRANCE [43³2.4'N 6²7.6'E], H. Cagniant (Casevitz-Weulersse \& Galkowski 2009).

Camponotus nylanderi Emery, 1921 (sub-family Formicinae). Outdoor in Cannes, FRANCE $\left[43^{\circ} 33.0^{\prime} \mathrm{N} 7^{\circ} 1.2^{\prime} \mathrm{E}\right], \mathrm{H}$. Cagniant.

Cardiocondyla obscurior Wheeler, 1929 (sub-family Myrmicinae). Paris, FRANCE

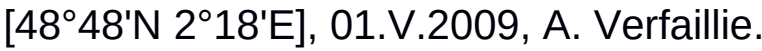

Dorylus fulvus (Westwood, 1839) (sub-family Dorylinae). Outdoor in Ajaccio, FRANCE [415․ 5 'N $\left.8^{\circ} 44.4^{\prime} \mathrm{E}\right], 1899$, Dr. Joseph, and Rochefort-sur-mer, FRANCE [4556.4'N 06.0'W], Giraud (Bondroit 1918).

Lepisiota nigra (Dalla Torre, 1893) (sub-family Formicinae). Outdoor in BourgAchard, FRANCE [49²1.0'N 049.2'E], 2010, P. Guérin.

Nylanderia fulva (Mayr, 1862) (sub-family Formicinae). Outdoor in Saint-Raphaël, FRANCE [4324.6'N 6²6.8'E], 1939-1948, F. Bernard (Bernard 1949).

Oecophylla sp. (sub-family Formicinae). Inside buildings in Carcassonne, FRANCE

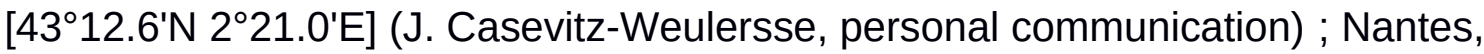
FRANCE [47ำ $\left.12^{\prime} \mathrm{N} 1^{\circ} 36^{\prime} \mathrm{W}\right], 2015, \mathrm{~F}$. Diemerts (ERFA (group) 2017).

Plagiolepis schmitzii Forel, 1895 (sub-family Formicinae). Outdoor in PortVendres, FRANCE $\left[42^{\circ} 31.2^{\prime} \mathrm{N} 3^{\circ} 6.6^{\prime} \mathrm{E}\right]$, L. Passera (H. Cagniant, personal communication). 
Technomyrmex albipes (Smith, 1861) (sub-family Dolichoderinae). Outdoor in Narbonne, FRANCE [43⒑98'N 30.12'E], 10.XII.2015, C. Lebas.

Tetramorium calidum Forel, 1907 (sub-family Myrmicinae). Inside a building in Toulouse, FRANCE $\left[43^{\circ} 37.2^{\prime} \mathrm{N} 1^{\circ} 22.2^{\prime} \mathrm{E}\right]$, J.-L. Marrou (H. Cagniant, personal communication).

Tetraponera allaborans (Walker, 1859) (sub-family Pseudomyrmecinae). Outdoor in Engis, BELGIQUE [50³4.8'N 5²4'E], 2003, M. Dethier (Dekoninck, Maelfait, et al. 2006).

Detection of the maintained introduced species

Our study in mainland France and Belgium revealed the presence of three permanently introduced and fifteen maintained ant species. We recorded a hundred occurrences of these fifteen maintained ants, and fifty-three of these occurrences had not been published before. The number of occurrences is highly variable between species (Fig. 2), ranging from one to twenty-one. Hypoponera punctatissima is the most commonly fund ant, mostly outdoors, but it is unsure whether this ant is an introduced species. The other most common species are Hypoponera ergatandria, Tapinoma melanocephalum, Monomorium pharaonis and Technomyrmex vitiensis (Fig. 2).

Forty-eight of one hundred occurrences came from twenty-two tropical greenhouses and tropical aquatic parks (among which eleven were surveyed specifically for this study) that were investigated to find ants. Between one and five species of 
maintained introduced ants live in each of these buildings (1.8 on average). The building where five species have been mentioned is the tropical greenhouse of the Jardin des Plantes de Paris, where occurrences span between 1878 and 2016. However, the five species have not been reported simultaneously. In this paper we reported occurrences dating from 1856 to 2017, 72\% of which were collected after 1990.

\section{Discussion}

The main results of this study are the detection of exotic ants in every heated building we inspected and of Technomyrmex ( $T$. vitiensis or $T$. difficilis) ants in five of the eleven buildings investigated between 2014 and 2016.

The first part of the discussion is dedicated to the description of the biology for the permanently (first three species) and maintained introduced ants, which are the most at risk of becoming invasive.

Lasius neglectus. Dark brown ant, about $3.5 \mathrm{~mm}$ long (Fig. 3a). In France, it is hardly distinguished from two indigenous species: Lasius alienus and Lasius lasioides. It is native to Western Asia and has invaded Europe recently (Seifert 2000). This species is well adapted to temperate climates. It is commonly found on roadsides (Gippet et al. 2017) and can live inside houses, where it is considered a pest. It has been found inside greenhouses in some countries (Dekoninck et al. 2010) and protects sap-feeding hemipterans (especially scale insects) while feeding on their honeydew (Van Loon et al. 1990). Each colony is composed of several nests, each of which contains many queens (Van Loon et al. 1990). Lasius 
neglectus is the only strongly polygynous Lasius species in Europe. Colonies can extend and disperse by budding. Contrary to other Lasius species, virgin females do not seem to fly to mate or disperse (Seifert 2000; Espadaler \& Rey 2001). The rapid expansion of this species seems to result from accidental human-mediated dispersion that commonly occurs for polygynous species.

Linepithema humile. Brown ant, 2.5 to $3 \mathrm{~mm}$ long (Fig. 3b). Native to the watershed of the Paraná River in South America (Wild 2004), it has been introduced outdoors in most of the regions of the world with a Mediterranean climate, at the end of the $19^{\text {th }}$ century (Wetterer et al. 2009). In cooler areas, it is only found in some buildings. It has a negative impact on biodiversity where it is introduced (Cole et al. 1992). After the first phase of expansion, some populations began to decline (Cooling et al. 2012). This ant can be found along the Mediterranean coast from Spain to Italy, in Corsica and on the Atlantic coast in Portugal, where it forms supercolonies across thousands of kilometres along the coast (Giraud et al. 2002): a series of small nests are exchanging queens and brood without any sign of aggression. Only three supercolonies have been described in Europe (Blight et al. 2012), suggesting a low number of independent introductions. It is a common ant in European greenhouses and is sometimes encountered in North-American greenhouses (Wetterer et al. 2009). It protects hemipterans and feeds on the honeydew they produce (Vega \& Rust 2001). Nests can be found in various ground cavities and they all contain multiple queens. New colonies are formed by budding. Outside of the buildings, this species goes through a hibernation period, which may also be the case in greenhouses with passive heating systems. It is hard to eradicate this ant and cooling down greenhouses during winter does not seem efficient. Other introduced 
species like Technomyrmex ants can outcompete Argentine ants inside greenhouses, but may be equally problematic for plants.

Monomorium carbonarium. Entirely black and shiny, 2 mm long (Fig. 3c). This species is known from the Azores, Madeira and the Atlantic coast of Portugal, Spain, and France (Espadaler \& Collingwood 2000). The Atlantic coast populations have most likely been introduced from Macaronesia. This species is mostly found outdoors (Espadaler \& Collingwood 2000, Galkowski 2008), but they can also survive inside buildings (Odilon Redon High School, Pauillac, France, C. Galkowski). They are mostly found in humid areas with loamy sandy soils on the coast. Apart from the coast, it is mostly found in urban areas around pools. These ants nest directly in the ground. Each nest is composed of many workers and queens. When introduced to a new area, they often become dominant and reduce the ant diversity in the area (Galkowski 2008).

Brachymyrmex sp. Light brown, 1.5 to $2 \mathrm{~mm}$ long. Brachymyrmex is a tropical genus that needs taxonomic revision. Different species have settled outside of their natural area and many were accidentally introduced inside greenhouses. Most species nest in the ground. Some of them protect root hemipterans.

Hypoponera ergatandria. Light brown, about $2.5 \mathrm{~mm}$ long (Fig. 3d). This species is morphologically like to Hypoponera punctatissima and is considered as a synonym species by some authors (Bolton \& Fisher 2011). This tropical ant is probably native to Africa and was accidentally introduced outdoor everywhere in the World between the tropics. In Europe, it has been found inside heated buildings (greenhouses, plant stores, museums) in the following countries: Belgium, Germany, England, Spain, France, Holland, Poland, Czech Republic, Switzerland (Bernard 1968; Boer \& 
Vierbergen 2008; Seifert 2013) and is most likely present in most tropical greenhouses in Europe. It is unsure yet whether it could survive outdoor like $H$. punctatissima. Hypoponera ergatandria lives exclusively underground and hunts small arthropods under leaf litter. It does not forage on plants and does not protect any hemipterans on the upper parts of the plants. Inside greenhouses, these ants dig galleries under flowerpots, stones, dead trees, and branches wherever the soil is humid. It can be hard to detect this ant that quickly runs away from the light, but was still found in four French greenhouses since 2015 and may be even more common. Each colony contains multiple queens (Seifert 2013). Queens are from two different types: some have wings and can fly, while some are "ergatoid" queens morphologically similar to workers. Mating occurs inside the nest (Seifert 2013). This species is mostly dispersed by humans carrying plants or soil. Surprisingly, it is the only introduced Ponerinae species found inside buildings in France. Furthermore, none of the samples we collected inside buildings were identified as $H$. punctatissima that has very similar traits, even though this one is mentioned outdoor in France and Belgium (Wegnez et al. 2012; <http://antarea.fr/fourmi/?repartition/repertition-especes.html?espece=5>). Hypoponera punctatissima. Light brown, about $2.5 \mathrm{~mm}$ long (Fig. 3e). Bolton and Fisher (2011) describe the biology of this species precisely but it is not possible to determine whether they refer to $H$. punctatissima or $H$. ergatandria as they consider these species as synonyms. This species seems to be anthropophilic and may have been introduced by human activities in many parts of the world (Delabie \& Blard 2002). McGlynn (1999) consider this species as native to Europe, but other authors mention it as an introduced species (Bolton \& Fisher 2011; Wegnez et al. 2012; 
Seifert 2013). In France and Belgium, it is mostly found outdoors and rarely indoors (Belgium). Most of the specimens that were collected are swarming drones and reproductive females. In contrast to Hypoponera ergatandria, it is rarely found inside greenhouses. It is unsure yet whether there are stable outdoor populations of this species; the ants found outside buildings might just be forming temporary nests after introductions or come from colonies swarming from the buildings. This species lives exclusively in the ground and in the litter, where it preys on small arthropods. It does not forage on plants or protect hemipterans.

Monomorium pharaonis. Yellow with dark gaster, about $2 \mathrm{~mm}$ long (Fig. 3f). This tropical species, native to Asia (Wetterer 2010), has been introduced worldwide. Between the tropics it is mostly found outdoor and indoor in urban areas. Under temperate climate it can only survive in heated buildings but has been mentioned outdoors multiple times (Wetterer 2010). It seems to live in houses and hospitals (Cornwell 1978; Edwards \& Baker 1981). In hospitals, it is a risk for public health as it can carry diseases (Beatson 1972) and contaminate sterile equipment. This species is common in buildings (Bondroit 1918; Bernard 1968) and can be found in most European countries (Wetterer 2010). It was the first introduced species reported in France, along with Paratrechina longicornis (Nylander 1856). However, little is known about its occurrence in France and Belgium. A single colony can be made of multiple nests with multiple queens. Nests can be found in any type of gap, even those very narrow. Colonies migrate frequently and can disperse by budding, facilitating accidental dispersion by humans.

Nylanderia vividula. Brown, about 2 mm long (Fig. 3g). Head and gaster darker, with many thick erected hairs. The Nylanderia genus is found worldwide and has 
more than 130 species that can hardly be distinguished from one another. Nylanderia vividula is native to North America. Despite many Nylanderia species being invasive, taxonomists started to pay attention to this genus only recently (LaPolla et al. 2011; Kallal \& LaPolla 2012). For this reason, it is challenging to identify specimens that have been introduced outside of their natural range (LaPolla et al. 2011). Ants previously identified as Nylanderia vividula in the literature may belong to other species. Nylanderia ants have been found in many European countries, inside buildings but also outdoors in the extreme South of Europe. Paratrechina longicornis. Dark brown, about $2.5 \mathrm{~mm}$ long. Body with many thick, long erected hairs, symmetrical along the bilateral body plan of the ant (Fig. 3h). Very long antennae. Paratrechina longicornis is a tropical species probably native to South-East Asia (Wetterer 2008). It has been introduced worldwide and has invaded the coasts and disturbed habitats of the tropics (Wetterer 2008). Under temperate climates, it is only found in heated buildings and has been observed in most European countries. In France, it was reported from 1856 to 1968 inside greenhouses, especially in Paris (Nylander 1856; Emery 1878; André 1883; Emery 1910; Bondroit 1918; Bernard 1968). We however did not detect this ant inside greenhouses during this study. This species has been observed protecting hemipterans and collecting honeydew (Wetterer et al. 1999; Wetterer 2008). A single colony can be made of many nests containing multiple queens (Yamauchi \& Ogata 1995). Workers depend on sexual reproduction, but queens are genetically identical to their mothers and drones to their fathers (Pearcy et al. 2011).

Pheidole anastasii. Yellow ant. The cuticle is punctuated on the whole body, resulting in a dull aspect. Just like for any Pheidole species, there is a strong 
dimorphism between the major workers that measure 3 to $3.5 \mathrm{~mm}$ and the minor workers that are only about $2 \mathrm{~mm}$ long. This tropical species comes from Central America. It has been seldom mentioned in North American and European greenhouses. The morphological differences between this species and Pheidole bilimeki have only been established recently (Longino \& Cox 2009). Some identifications in previous works might thus refer to Pheidole bilimeki (Sarnat et al. 2015). Pheidole anastasii is omnivorous and workers forage on the ground and on the trees. They nest in any type of plant cavities (Longino \& Cox 2009).

Pheidole bilimeki. Brown ant. The cuticle is punctuated on the whole body, resulting in a dull aspect (Fig. 3i). Just like Pheidole anastasii, there is a strong dimorphism between the major workers that measure 3 to $3.5 \mathrm{~mm}$ and the minor workers that are only about $2 \mathrm{~mm}$ long. This tropical species comes from Central America (Sarnat et al. 2015). It has been seldom seen in greenhouses in North America and in the following European countries: Germany, United Kingdom, The Netherlands (identified as Pheidole anastasii according to Sarnat et al. 2015), Ireland, Switzerland (Forel 1908; Stelfox 1927; Boer \& Vierbergen 2008). In their natural area, these ants are considered as pests because they enter houses (Longino \& Cox 2009). They are omnivorous and nest in the ground.

Pheidole megacephala. Brown (Fig. 3j). Just like for any Pheidole species, there is a strong dimorphism between the major workers that measure 3 to $3.5 \mathrm{~mm}$ and the minor workers that are only about $2 \mathrm{~mm}$ long. This is a tropical species originating from Africa (Wetterer 2012). Following its accidental dispersal by humans, it is now widespread outdoors between the tropics and inside heated buildings in Europe and New-Zealand (Wetterer 2012). This highly invasive species has been seen in the 
buildings of the following European countries: England, The Netherlands, Germany, France and Italy (Wetterer 2012). It protects sap-feeding hemipterans and collects their honeydew (Wheeler 1922; Beardsley et al. 1982; González-Hernández et al. 1999). It nests in the ground, under rocks or under the bark of dead trees and in various types of cavities on the floor. Each colony has multiple queens. New colonies are formed by budding (Beardsley et al. 1982). Budding facilitates human-mediated dispersal because colonies can be split and translocated by humans and form new nests.

Plagiolepis alluaudi. Yellow ants of about $1.5 \mathrm{~mm}$ long (Fig. 3k). This tropical species originates from Africa, probably in Madagascar where it is commonly found in forests (Wetterer 2014). It has spread to Asia and Oceania, and is found on a few islands of the American Atlantic coast. In Europe, it can be found inside the greenhouses of several countries (England, Switzerland, Ireland, Scotland, Germany and The Netherlands) (Wetterer 2014). It protects sap-feeding hemipterans and feed on their honeydew (Gonzalez-Hernandez et al. 1999). A colony can be made of many nests containing multiple queens. Outdoors, it nests in a variety of very small spaces: under bark of dead trees, in the holes made by wood-boring insects, under grass clumps, to name a few. Indoors, it nests in cavities formed between the stipes, petioles or leaves and plant stems. It nests preferentially above ground, but is commonly found under flowerpots. The nests are opportunistic, and the ants do not usually build structures or dig burrows. Each nest contains multiple queens, which facilitates their dispersal when materials or plants are exchanged. These ants are in addition very small and pale yellow, and can be hard to detect when they are present in small numbers. 
Tapinoma melanocephalum. Bicolor ant (head and thorax dark brown, gaster light yellow) of about $1.5 \mathrm{~mm}$ (Fig. 3l). This tropical species is native to the Indo-Pacific region (Wetterer 2009a). It has been accidentally introduced everywhere between the tropics by human activities. Under temperate climate in the northern hemisphere, it has been observed inside the buildings (houses, restaurants, hospitals, tropical greenhouses) in the following countries: Canada, USA, England, Scotland, Germany, Finland, Sweden, Norway, France, Belgium, Switzerland, Italy, Spain, Austria, Denmark, The Netherlands, Romania, and Russia (Wetterer 2009a). In France, it is thought to be present in every tropical greenhouse, but has only been mentioned twice in the literature. This species protects various species of sapfeeding insects and feed on their honeydew (Venkataramaiah \& Rehman 1989). It nests in a range of cavities, is very opportunistic and do not build or dig much. A whole nest can sometimes be found between two dead leaves. Colonies are made of many connected nests and usually contain many queens. Nests are regularly moved. These life traits can explain why it has often been dispersed by humans when translocating materials, plants or goods.

Technomyrmex difficilis. Black ant, 3.5 to $4 \mathrm{~mm}$ (Fig. $3 \mathrm{~m}$ ). This tropical species is probably native to Madagascar (Wetterer 2013). It has been introduced to the southern part of North America, in South-East Asia, and in Oceania (Wetterer 2013). In the USA, it has been observed inside buildings in temperate climate. However, the actual distribution of this species is poorly understood since it was only distinguished from Technomyrmex albipes in 2007 (Bolton 2007). It had never been reported in Europe before. Even though we detected it only in one building in France, it was well established in this greenhouse and is at risk of being introduced to other places, 
especially if flower pots were to be translocated. We therefore decided to classify this species as a maintained introduced ant. This species protects sap-feeding hemipterans and feeds on their honeydew (Warner 2003). Outdoors, nests are mostly found in the cavities formed between the stipes, petioles, and leaves when they are close to the stem, and more rarely in cavities at the ground level and in masonry cracks. As with other ants in the Technomyrmex genus, each colony is composed of many temporary nests containing very few queens but many egg-laying inter-caste (a morphological mix between queens and workers) (Bolton 2007). Colonies can disperse by budding.

Technomyrmex vitiensis. Black ant, 3.5 to $4 \mathrm{~mm}$ (Fig. $3 \mathrm{n}$ ). This tropical species is probably native to South-East Asia. It has been introduced to many tropical greenhouses in Europe: Germany, Austria, Belgium, The Netherlands (identified as T. albipes), United Kingdom, Czech Republic (Bolton 2007; Boer \& Vierbergen 2008; Dekoninck et al. 2010; Pech \& Bezděk 2016). It has also been found in San Francisco in the USA (Bolton 2007). It had never been reported in mainland France before. This species protects sap-feeding hemipterans and feeds on their honeydew (Bolton 2007). Nests are mostly found in the natural cavities occurring in plants, for example between the stipes, petioles, and leaves when they are close to the stem. They can also be found in the litter, in pieces of dead wood and under the stones (Bolton 2007). They do not build or dig much, and they move their nests rapidly when disturbed. As for other Technomyrmex species, each colony is made of multiple nests that contain very few queens and many inter-caste individuals (Oettler \& Heinze 2009). Colonies can disperse by budding. With such traits, it seems likely that human activities can disperse this species, especially when relocating plants. 
Tetramorium bicarinatum. Brown-orange with a darker gaster, about $4 \mathrm{~mm}$ long (Fig. 3o). The cuticle is highly sculpted, reticulated on the thorax and with longitudinal wrinkles on the head. This is a tropical species native to the Indo-Pacific. It has been introduced to every tropical and subtropical regions of the world (Wetterer 2009b). However, it is uncommon in continental Africa and Western Asia. In Europe, it is found inside greenhouses and heated buildings in many countries (Germany, England, Austria, Belgium, Scotland, Spain, France, Hungary, Northern Ireland, Italy, Monaco, Norway, The Netherlands) (Wetterer 2009b). This species is highly competitive. It maintains and protects sap-feeding hemipterans and feeds on their honeydew (Mann 192; Greenslade 2008). It is omnivorous, with workers foraging on the ground and on plants. Nests are found in the ground.

Tetramorium groupe simillimum. Yellow to light brown, 2-2.5 mm long (Fig. 3p). Cuticle with thin wrinkles. Species in the Tetramorium simillimum group are native to tropical Africa (Wetter \& Hita Garcia 2015). Tetramorium simillimum (Smith, 1851) and Tetramorium caldarium (Roger, 1857) are invasive and have been mentioned in different greenhouses and heated buildings in Europe. Not long after they were described, these two species were considered synonyms, and then distinct species again in 1979 (Bolton 1979). Tetramorium simillimum has only been mentioned by Bernard (1968) from "various greenhouses" in France. Since the two species were considered synonyms at this time, it is not possible to determine which species was mentioned. However, Tetramorium caldarium seem more common inside greenhouses and heated buildings in Europe (Wetterer \& Hita Garcia 2015). 
Ants from the Technomyrmex albipes group were already known from most tropical greenhouses throughout Europe, but had never been reported in France so far. These ants seem to have invaded European greenhouses recently. They are only commonly reported by the end of the $20^{\text {th }}$ century. It would be unlikely that they went unnoticed by the many famous European myrmecologists of the end of the $19^{\text {th }}$ and of the beginning of the $20^{\text {th }}$ century. For example, Paratrechina longicornis, Monomorium pharaonis and Tetramorium bicarinatum were already reported respectively by 1856, 1856 and 1918 in French buildings (Nylander 1856; Bondroit 1918) and in Dutch buildings in 1909, 1877 and 1909 respectively (Boer \& Vierbergen 2008), whereas Technomyrmex ants were first reported in France and The Netherlands in 2014 and 1988 respectively. Paratrechina longicornis and Tetramorium bicarinatum were not detected during our 2014-2016 survey. Monomorium pharaonis was not detected either and seem to only survive in houses and apartments. Our study shows that the composition of the community of introduced ants in heated buildings varies with time, similarly to reports from Boer and Vierbergen (2008). Changes in plant trade and importations could partially explain this (Bertelsmeier et al. 2017), and the introduction of new species of ants may have led to other species disappearing as observed with other invasive species (Lohrer \& Whitlatch 2002). The growing awareness about various animal species living in the soil has also led to the adoption of new regulations restricting soil importations. These regulations may have discouraged the introduction of groundnesting species but not of arboreal ant species. 
We investigated whether tropical greenhouses could be entry points for introduced species because they regularly import exotic plants. However, the three invasive ant species that survive outside greenhouses in France, Linepithema humile, Lasius neglectus and Monomorium carbonarium, have not been introduced through greenhouses. On the contrary, species like Paratrechina longicornis and Tetramorium bicarinatum, considered invasive in tropical and sub-tropical areas, have never been found outside buildings even though they are known from greenhouses for more than a hundred years. Tropical ants have narrower temperature ranges than ants from temperate climates (Diamond et al. 2012), which limits the invasiveness of these species in France and Belgium. These results suggest that greenhouses are not currently the main source of invasive species, and highlight the need to collaborate with customs to investigate the role of plant or ant trade in the introduction of exotic species. It is unclear whether climate change will one day allow these species to spread from greenhouses and survive outdoors, although many of the ants we found inside heated buildings had shared features with known outdoor invasive ant species (Bertelsmeier et al 2017). The list we provide along with key biological features is a first step to assess risks of future invasions in mainland France and Belgium.

Presently, introduced ants that are found indoors are more problematic for the plants, since they protect and disperse sap-feeding hemipterans. When asked about inconveniences caused by the ants, the staff members did not report any for the buildings where Tapinoma melanocephalum was dominant. On the contrary, damages caused by Linepithema humile, Plagiolepis alluaudi and Technomyrmex 
ants were systematically reported. The staff members reported ants protecting and dispersing sap-feeding insects (especially scale insects) (Fig. 4b and 4c) and sometimes killing biological control agents (parasitoid hymenopterans) (Fig. 4d). Some of them also reported that biological control agents were inefficient when ants were present. Ant baits were reported to decrease the number of ants, although they did not allow for the eradication of the colonies. Decreasing the temperature during several weeks in winter, a method used by the Naturospace of Honfleur, could help in reducing the number of ants, but cannot be applied to every kind of buildings. Some of these organizations also introduced natural predators, such as birds (Naturospace) or dendrobates (botanical garden of Meise, Belgium). The Amazonian greenhouse of the Lunaret zoo of Montpellier also has free flying birds, but this does not seem to have a significant impact on ant populations. A clear need for the development of environmentally friendly methods to control these ants was identified. We suggest that new plants should be quarantined in buckets surrounded by water and closely inspected to detect the presence of exotic insects before being moved inside heated buildings. Original soil should also be removed, heated above $60^{\circ} \mathrm{C}$ and replaced.

In temperate climates, tropical greenhouses are like islands for tropical ants, providing them with limited space and resources. We often observed a clear dominance of one species in each building. For example, Linepithema humile was dominant in the greenhouses of the botanical gardens of Meise (Belgium) and Tours (France); Plagiolepis alluaudi in the large greenhouse of the Jardin des Plantes de Paris (France) (Fig. 4a) and in the greenhouse of the botanical garden of Paul 
Sabatier University in Toulouse (France); Tapinoma melanocephalum in the greenhouses of the arboretum of Chevreloup (France), in the zoo of the Jardin des Plantes de Paris (France) and in the greenhouses of the botanical gardens of Grenoble, Metz and Strasbourg (France); Technomyrmex difficilis in the greenhouse of the botanical garden of Lyon (France); and Technomyrmex vitiensis in the Amazonian greenhouse of the Lunaret zoo in Montpellier, the Naturospace of Honfleur (France) and in the greenhouses of the botanical garden of Ghent University (Belgium). The limited resources could explain the low number of introduced species living simultaneously in the same greenhouse. Invasive species can compete directly for the same food sources (Lach 2005). In 2016, two of us inspected the large tropical greenhouse of the Jardin des Plantes de Paris (built at the end of the $19^{\text {th }}$ century) for three hours and found only four introduced species (three ground nesting species: Pheidole megacephala, Brachymyrmex cordemoyi and Hypoponera ergatandria, and one arboreal species: Plagiolepis alluaudi). During the repeated surveys in 2014, 2015 and 2017 in the Amazonian greenhouse of the Lunaret zoo of Montpellier (built in 2006), only three introduced species were found (two ground nesting species: Linepithema humile and Hypoponera ergatandria, and one arboreal species: Technomyrmex vitiensis). Linepithema humile was already common in this area before the greenhouse was built and was already well established inside the greenhouse in 2014 (personal observation, R. Blatrix). It was however not detected in 2015 and 2017, possibly because of Technomyrmex vitiensis was then dominant in this building. Inside greenhouses, interspecific competition is probably high and genetic diversity extremely low, which may also cause rapid changes in the composition of ant communities. These factors make 
greenhouses candidates for the study of island biogeography and metapopulation dynamics.

\section{Acknowledgements}

We thank the staff members of the artificial tropical spaces that have allowed us to collect or directly sent us samples of ants, and helped us all along the study: botanical garden of Caen (N. Hubert); Chèvreloup arboretum (J.-M. Doremus) ; Museum of Natural History of Grenoble (S. Poletti) ; Naturospace of Honfleur (B. Damico, B. Mery) ; butterfly greenhouse of Hunawihr (Mr. Bueche) ; botanical garden of Liège ; botanical garden of Lyon (P. Avoscan, P. Boucheix, G. Cianfarani, G. Deparis, D. Deruaz, A. Donzet, F. Lardiere, F. Pautz, C Rimbaud, E. Rostaing, J.-M. Tete, F. Trescarte) ; botanical garden of Meise ; botanical garden of Metz (A. Rotini) ; Lunaret zoo of Montpellier (L. Gomel, D. Gomis, A. Françoise, R. Guicherd) ; botanical garden conservatory of Nancy (A. Bour , L. Gardeux, L. Peru, M. Remy) ; Pairi Daiza park of Brugelette ; Museum of Natural History of Paris (K. Ben Youb, E. Joly, S. Languille, F. Lemoine, J. Munier, R. Nattier, B. Noël, M. Saint Jalme, F. Saint-Hillier) ; Ecological station of Paris 7 University (O. Babiar) ; botanical garden of Strasbourg University (F. Tournay) ; botanical garden Henri Gaussen of Paul Sabatier University in Toulouse (N. Séjalon-Delmas) ; botanical garden of Tours (R. Cézé, M. Froger, R. Saulnier). We also would like to thank B. Kaufmann and J. Gippet for sharing all of their data on the occurrence of Lasius neglectus with us. We thank H. Cagniant, H. Callot, J. Ho-Huu and C. Lebas for the personal observations and ant samples they shared with us. Data from Corsica have 
been obtained with the financial support of the Corsican Office for the

Environnement and AntArea. We thank Duncan Jaroslow for his useful comments on the English version of the manuscript.

\section{References}

André E. 1883. Species des hyménoptères d'Europe et d'Algérie. Beaune, France. Beardsley JW, Su TH, McEwen FL, Gerling D. 1982. Field investigations on the interrelationships of the big-headed ant, the gray pineapple mealybug, and pineapple mealybug wilt disease in Hawaii. Proceedings of the Hawaiian Entomological Society. 24:51-67.

Beatson SH. 1972. Pharaoh's ants as pathogen vectors in hospitals. The Lancet. 299:425-427.

Bauer M, Dullinger S, Moser D, Essl F. 2015. An analysis of weed floras in nurseries: Do polytunnels serve as ports of entry for alien plant species?. Flora-Morphology, Distribution, Functional Ecology of Plants. 213:6-11.

Bernard F. 1949. Notes sur les fourmis de France. II. Peuplement des montagnes méridionales. Annales de la Société entomologique de France. 115:1-36.

Bernard F. 1968. Faune de l'Europe et du bassin méditerranéen. 3. Les fourmis (Hymenoptera Formicidae) d'Europe occidentale et septentrionale. Paris, France: Masson.

Bernard F. 1983. Les fourmis et leur milieu en France méditerranéenne. Paris, France: Lechevalier. 
Bertelsmeier C, Ollier S, Liebhold A, Keller L. 2017. Recent human history governs global ant invasion dynamics. Nature Ecology \& Evolution. 1:0184.

Blatrix R, Geniez P. 2015. Les fourmis de nos serres. Sauvages \& cultivées. 7:2627.

Blight O, Berville L, Vogel V, Hefetz A, Renucci M, Orgeas J, Provost E, Keller L. 2012. Variation in the level of aggression, chemical and genetic distance among three supercolonies of the Argentine ant in Europe. Molecular Ecology. 21:4106-4121.

Boer P, Vierbergen B. 2008. Exotic ants in The Netherlands (Hymenoptera: Formicidae). Entomologische Berichten (Amsterdam). 68:121-129.

Bolton B. 1979. The ant tribe Tetramoriini (Hymenoptera: Formicidae). The genus Tetramorium Mayr in the Malagasy region and in the New World. Bulletin of the British Museum, Natural History Entomology Series. 38:129-181.

Bolton B. 2007. Taxonomy of the dolichoderine ant genus Technomyrmex Mayr (Hymenoptera: Formicidae) based on the worker caste. Contributions of the American Entomological Institute. 35:1-150.

Bolton B, Alpert GD, Ward PS, Naskrecki P. 2006. Bolton's catalogue of ants of the world: 1758-2005. Cambridge, USA: Harvard University Press.

Bolton B, Fisher BL. 2011. Taxonomy of Afrotropical and West Palaearctic ants of the ponerine genus Hypoponera Santschi (Hymenoptera: Formicidae). Zootaxa. 2843:1-118.

Bondroit J. 1911. Fourmis exotiques importées au jardin botanique de Brussels. Annales de la Société entomologique de Belgique. 55:14. 
Bondroit J. 1918. Les fourmis de France et de Belgique. Annales de la Société entomologique de France. 87:1-174.

Casevitz-Weulersse J, Galkowski C. 2009. Liste actualisée des fourmis de France (Hymenoptera, Formicidae). Bulletin de la Société entomologique de France. $114: 475-510$.

Cole FR, Medeiros AC, Loope LL, Zuehlke WW. 1992. Effects of the Argentine ant on arthropod fauna of Hawaiian high-elevation shrubland. Ecology. 73:13131322.

Cooling M, Hartley S, Sim DA, Lester PJ. 2012. The widespread collapse of an invasive species: Argentine ants (Linepithema humile) in New Zealand. Biology Letters. 8:430-433.

Cornwell PB. 1978. The incidence of pest ants in Britain. International Pest Control. 20:10-14.

Dekoninck W, Brouckaert D. 2011. Paratrechina longicornis (Latreille, 1802) another introduced and invasive ant species discovered in Belgium. Bulletin de la Société royale belge d'Entomologie. 147:99-101.

Dekoninck W, De Baere C, Mertens J, Maelfait J-P. 2002. On the arrival of the Asian invader ant Lasius neglectus in Belgium. Bulletin de la Société royale belge d'Entomologie. 138:45-48.

Dekoninck W, Ignace D, Wegnez P. 2010. Records of a new pest ant species in Belgium, Technomyrmex vitiensis Mann, 1921. Bulletin de la Société royale belge d'Entomologie. 146:86-90.

Dekoninck W, Maelfait J-P, Vankerckhoven F, Baugnée J-Y, Grootaert P. 2006. An update of the checklist of the Belgian ant fauna with comments on new 
species for the country (Hymenoptera, Formicidae). Belgium Journal of Entomology. 8:27-41.

Dekoninck W, Wegnez P, Espadaler X, Grootaert P. 2006. First record of infestation of the ghost ant Tapinoma melanocephalum (Fabricius, 1793) in Belgium (Hymenoptera, Formicidae)-A new indoor pest problem for the country. Bulletin de la Société royale belge d'Entomologie. 142:25-28.

Delabie JHC, Blard F. 2002. The tramp ant Hypoponera punctatissima (Roger) (Hymenoptera: Formicidae: Ponerinae): new records from the southern hemisphere. Neotropical Entomology. 31:1-3.

Diamond SE, Sorger DM, Hulcr J, Pelini SL, Del Toro I, Hirsch C, Oberg E, Dunn RR. 2012. Who likes it hot? A global analysis of the climatic, ecological, and evolutionary determinants of warming tolerance in ants. Global Change Biology. 18:448-456.

Edwards JP, Baker LF. 1981. Distribution and importance of the Pharaoh's ant Monomorium pharaonis (L) in National Health Service Hospitals in England. Journal of Hospital Infection. 2:249-254.

Emery C. 1878. Catalogo delle formiche esistenti nelle collezioni del Museo Civico de Genova. Parte seconda. Formice dell'Europa e delle regioni limitrofe in Africa e in Asia. Annali del Museo Civico di Storia Naturale Giacomo Doria. 12:43-59.

Emery C. 1910. Beiträge zur Monographie der Formiciden des paläarktischen Faunengebietes. (Hym.). Teil X. Deutsche Entomologische Zeitschrift. 1910:127-132. 
Emery C. 1916. Fauna Entomologica Italiana. Hymenoptera Formicidae. Bullettino della Società Entomologica Italiana. 47:79-275.

ERFA (collectif). 2017. Bilan annuel de l'enquête sur la répartition des fourmis armoricaines. Rennes, France: GRETIA.

Espadaler X, Collingwood CA. 2000. Transferred ants in the Iberian Peninsula. Nouvelle Revue d'Entomologie. 17:257-263.

Espadaler X, Rey S. 2001. Biological constraints and colony founding in the polygynous invasive ant Lasius neglectus (Hymenoptera, Formicidae). Insectes Sociaux. 48:159-164.

Forel A. 1908. Fourmis de Costa-Rica, récoltées par M. Paul Biolley. Bulletin de la Société Vaudoise des Sciences Naturelles. 44:35-72.

Galkowski C. 2008. Quelques fourmis nouvelles ou intéressantes pour la faune de France (Hymenoptera, Formicidae). Bulletin de la Société Linnéenne de Bordeaux. 143, N.S. 36:423-433.

Gippet, JM, Mondy N, Diallo-Dudek J, Bellec A, Dumet A, Mistler L, Kaufmann B. 2017. I'm not like everybody else: urbanization factors shaping spatial distribution of native and invasive ants are species-specific. Urban Ecosystems. 20:157-169.

Giraud T, Pedersen JS, Keller L. 2002. Evolution of supercolonies: the argentine ants of Southern Europe. Proceedings of the National Academy of Science of the USA. 99:6075-6079.

González-Hernández H, Reimer NJ, Johnson MW. 1999. Survey of the natural enemies of Dysmicoccus mealybugs on pineapple in Hawaii. BioControl. 44:47-58. 
Gouraud C. 2015. Bilan de l'année 2014: Atlas des fourmis de Loire-Atlantique (Hymenoptera, Formicidae). Rennes, France: GRETIA.

Greenslade P. 2008. Climate variability, biological control and an insect pest outbreak on Australia's Coral Sea islets: lessons for invertebrate conservation. Journal of Insect Conservation. 12:333-342.

Hugel S, Callot H, Delecolle JC. 2003. Insectes exotiques et/ou nouveaux pour la France dans les serres du Jardin botanique de Strasbourg. Bulletin de la Société entomologique de Mulhouse. 59:67-73.

Kallal RJ, Lapolla JS. 2012. Monograph of Nylanderia (Hymenoptera: Formicidae) of the world, part II: Nylanderia in the Nearctic. Zootaxa. 3508:1-64.

Lach L. 2005. Interference and exploitation competition of three nectar-thieving invasive ant species. Insectes Sociaux. 52:257-262.

LaPolla JS, Brady SG, Shattuck SO. 2011. Monograph of Nylanderia (Hymenoptera: Formicidae) of the World: An introduction to the systematics and biology of the genus. Zootaxa. 3110:1-9.

LaPolla JS, Hawkes, Fisher BL. 2011. Monograph of Nylanderia (Hymenoptera:

Formicidae) of the world, part I: Nylanderia in the afrotropics. Zootaxa. 3110:10-36.

Lohrer AM, Whitlatch RB. 2002. Interactins among aliens: apparent replacement of one exotic species by another. Ecology. 83:719-732.

Longino JT, Cox DJ. 2009. Pheidole bilimeki reconsidered (Hymenoptera:

Formicidae). Zootaxa. 1985:34-42.

Mann WM. 1920. Additions to the ant fauna of the West Indies and Central America. Bulletin of the American Museum of Natural History. 42:403-439. 
McGlynn TP. 1999. The worldwide transfer of ants: geographical distribution and ecological invasions. Journal of Biogeography. 26:535-548.

Miravete V, Roura-Pascual N, Dunn RR, Gómez C. 2014. How many and which ant species are being accidentally moved around the world? Biology Letters. $10: 20140518$

Nylander W. 1856. Synopsis des formicides de France et d'Algérie. Annales des Sciences Naturelles Zoologie et Biologie Animale. 5:51-109.

Oettler J, Heinze J. 2009. Polymorphism of female reproductives in the tramp ant Technomyrmex vitiensis (Hymenoptera: Formicidae: Dolichoderinae). Myrmecological News. 12:133-137.

Pearcy M, Goodisman MAD, Keller L. 2011. Sib mating without inbreeding in the longhorn crazy ant. Proceedings of the Royal Society B: Biological Sciences. 278:2677-2681.

Pech P, Bezděk A. 2016. Ergatomorph wingless males in Technomyrmex vitiensis Mann, 1921 (Hymenoptera: Formicidae). Journal of Hymenoptera Research. $53: 25-34$.

Rasplus JY, Villemant C, Paiva MR, Delvare G, Roques A. 2010. Hymenoptera. Chapter 12. BioRisk. 4:669-776.

Sarnat EM, Fischer G, Guénard B, Economo EP. 2015. Introduced Pheidole of the world: taxonomy, biology and distribution. ZooKeys. 543:1-109.

Seifert B. 2000. Rapid range expansion in Lasius neglectus (Hymenoptera, Formicidae) - an Asian invader swamps Europe. Deutsche Entomologische Zeitschrift. 47:173-179. 
Seifert B. 2013. Hypoponera ergatandria (Forel, 1893) - a cosmopolitan tramp species different from $H$. punctatissima (Roger, 1859) (Hymenoptera: Formicidae). Soil Organisms. 85:189-201.

Seifert B, d'Eustacchio D, Kaufmann B, Centorame M, Lorite P, Modica MV. 2017. Four species within the supercolonial ants of the Tapinoma nigerrimum complex revealed by integrative taxonomy (Hymenoptera: Formicidae). Myrmecological News. 24:123-144.

Stelfox AW. 1927. A list of the Hymenoptera Aculeata (sensu lato) of Ireland. Proceedings of the Royal Irish Academy Section B: Biological, Geological, and Chemical Science. 37:201-355.

Van Loon AJ, Boomsma JJ, Andrasfalvy A. 1990. A new polygynous Lasius species (Hymenoptera: Formicidae) from central Europe. I. Description and general biology. Insectes Sociaux. 37:348-362.

Vega SJ, Rust MK. 2001. The Argentine ant - A significant invasive species in agricultural, urban and natural environments. Sociobiology. 37:3-26.

Venkataramaiah GH, Rehman PA. 1989. Ants associated with the mealybugs of coffee. Indian Coffee. 43:13-14.

Wagner HC, Arthofer W, Seifert B, Muster C, Steiner FM, Schlick-Steiner BC. 2017. Light at the end of the tunnel: integrative taxonomy delimits cryptic species in the Tetramorium caespitum complex (Hymenoptrea: Formicidae). Myrmecological News. 25:95-129.

Warner JR. 2003. Bait preferences and toxicity of insecticides to white-footed ants Technomyrmex albipes (Hymenoptera: Formicidae) [MSc thesis]. Gainesville, USA: University of Florida. 
Wegnez P, Ignace D, Fichefet V, Hardy M, Plume T, Timmermann M. 2012. Fourmis de Wallonie (2003-2011). Série " Faune-Flore-Habitat " nº 8. Gembloux, Belgique: SPW-DGARNE.

Westphal MI, Browne M, MacKinnon K, Noble I. 2008. The link between international trade and the global distribution of invasive alien species. Biological Invasions. 10:391-398.

Wetterer JK. 2008. Worldwide spread of the longhorn crazy ant, Paratrechina longicornis (Hymenoptera: Formicidae). Myrmecological News. 11:137-149.

Wetterer JK. 2009a. Worldwide spread of the ghost ant, Tapinoma melanocephalum (Hymenoptera: Formicidae). Myrmecological News. 12:23-33.

Wetterer JK. 2009b. Worldwide spread of the penny ant, Tetramorium bicarinatum (Hymenoptera: Formicidae). Sociobiology. 54:811-830.

Wetterer JK. 2010. Worldwide spread of the pharaoh ant, Monomorium pharaonis (Hymenoptera: Formicidae). Myrmecological News. 13:115-129.

Wetterer JK. 2012. Worldwide spread of the African big-headed ant, Pheidole megacephala (Hymenoptera: Formicidae). Myrmecological News. 17:51-62.

Wetterer JK. 2013. Worldwide spread of the difficult white-footed ant, Technomyrmex difficilis (Hymenoptera: Formicidae). Myrmecological News. 18:93-97.

Wetterer JK. 2014. Worldwide spread of Alluaud's little yellow ant, Plagiolepis alluaudi (Hymenoptera: Formicidae). Myrmecological News. 19:53-59. Wetterer JK, Hita Garcia F. 2015. Worldwide spread of Tetramorium caldarium (Hymenoptera: Formicidae). Myrmecological News. 21:93-99. 
Wetterer JK, Miller SE, Wheeler DE, Olson CA, Polhemus DA, Pitts M, Ashton IW, Himler AG, Yospin MM, Helms KR, et al. 1999. Ecological dominance by Paratrechina longicornis (Hymenoptera: Formicidae), an invasive tramp ant, in biosphere 2. Florida Entomologist. 82:381-388.

Wetterer JK, Wild AL, Suarez AV, Roura-Pascual N, Espadaler X. 2009. Worldwide spread of the Argentine ant, Linepithema humile (Hymenoptera: Formicidae). Myrmecological News. 12:187-194.

Wheeler WM. 1922. The ants collected by the American Museum Congo Expedition. Bulletin of the American Museum of Natural History. 45:39-269.

Wild AL. 2004. Taxonomy and distribution of the Argentine ant, Linepithema humile (Hymenoptera : Formicidae). Annals of the Entomological Society of America. 97:1204-1215.

Yamauchi K, Ogata K. 1995. Social structure and reproductive systems of tramp versus endemic ants (Hymenoptera: Formicidae) of the Ryukyu Islands. Pacific Science. 49:55-68. 
Table 1: List of the alien ant species introduced in mainland France and Belgium (except those species only intercepted at entry points). F: France, B: Belgium, O: outdoor, I: indoor, MI: maintained introduced, PI: permanently introduced, TI: temporarily introduced, -: no data.

\section{Figure legends:}

Figure 1: Occurrences of the three permanently introduced species of ants, outdoor (red dots) and indoor (blue triangles). The actual distribution is probably larger.

Figure 2: Occurrences of maintained introduced ants in mainland France and Belgium. Data are represented in dark grey if collected before 1990 and light grey if they were collected after. We used date of publication as the year of observation for published data that were not associated with a collection date.

Figure 3: Photos of the main introduced ant species in mainland France and Belgium. Photos from AntWeb (www.antweb.org); photographers: April Nobile (e, g, k, m, n, o, p), Erin Prado (f), Michele Esposito (b, d), Ryan Perry (c), Shannon Hartman (j), Will Ericson (a, h), Zach Lieberman (i, l).

Figure 4: Presence and impact of exotic ants in tropical greenhouses. Plagiolepis alluaudi colony under a flowerpot (the pot has been moved to show the colony) (a). Plagiolepis alluaudi (b) and Technomyrmex vitiensis (c) protecting sap-feeding hemipterans. Technomyrmex vitiensis workers colonizing a piece of cardboard 
(splitted in two to show the colony) used to release biological control agents against hemipterans (d). Photos: Théotime Colin (a, b) and Rumsaïs Blatrix (c, d).

\section{Online supplementary material:}

Table S1: Occurrence data for temporary, maintained and permanently introduced ants in France and Belgium. 
Table 1.

\begin{tabular}{|c|c|c|c|c|c|c|c|}
\hline Species & Sub-family & Origin & $\mathbf{1}^{\text {st }}$ date $\mathbf{F}$ & Habitat F & $1^{\text {st }}$ date B & Habitat B & Status \\
\hline Aphaenogaster gemella & Myrmicinae & Africa & 1983 & $\mathrm{O}$ & - & - & $\mathrm{TI}$ \\
\hline Brachymyrmex & Formicidae & America & 2016 & I & 1908 & I & $\mathrm{MI}$ \\
\hline Camponotus barbaricus & Formicidae & North Africa & 2009 & $\mathrm{O}$ & - & - & $\mathrm{TI}$ \\
\hline Camponotus nylanderi & Formicidae & Italy & no date & $\mathrm{O}$ & - & - & $\mathrm{TI}$ \\
\hline Cardiocondyla obscurior & Myrmicinae & Asia & 2009 & $\mathrm{O}$ & - & - & $\mathrm{TI}$ \\
\hline Dorylus fulvus & Dorylinae & Africa & 1899 & $\mathrm{O}$ & - & - & $\mathrm{TI}$ \\
\hline Hypoponera ergatandria & Ponerinae & Africa & 1968 & I & 1909 & I & MI \\
\hline Hypoponera punctatissima & Ponerinae & $?$ & 1934 & $\mathrm{O}$ & 1990 & $\mathrm{Ol}$ & MI \\
\hline Lasius neglectus & Formicidae & Western Asia & 1981 & $\mathrm{Ol}$ & 1978 & $\mathrm{Ol}$ & $\mathrm{PI}$ \\
\hline Lepisiota nigra & Formicidae & Mediterranean basin & 2010 & $\mathrm{O}$ & - & - & $\mathrm{TI}$ \\
\hline Linepithema humile & Dolichoderinae & South America & 1921 & $\mathrm{Ol}$ & 1911 & I & $\mathrm{PI}$ \\
\hline Monomorium carbonarium & Myrmicinae & Macaronesia & 1970 & $\mathrm{Ol}$ & - & - & $\mathrm{PI}$ \\
\hline Monomorium pharaonis & Myrmicinae & Tropical Asia & 1856 & $\mathrm{Ol}$ & 2006 & $\mathrm{Ol}$ & MI \\
\hline Nylanderia fulva & Formicidae & South America & 1948 & $\mathrm{O}$ & - & - & $\mathrm{TI}$ \\
\hline Nylanderia vividula & Formicidae & America & 1968 & I & - & - & MI \\
\hline Oecophylla sp. & Formicidae & Old World & 2015 & I & - & - & $\mathrm{TI}$ \\
\hline Paratrechina longicornis & Formicidae & South-East Asia & 1856 & I & 2010 & I & MI \\
\hline Pheidole anastasii & Myrmicinae & Central America & 1968 & I & - & - & MI \\
\hline Pheidole bilimeki & Myrmicinae & Central America & 2005 & I & 1911 & I & MI \\
\hline Pheidole megacephala & Myrmicinae & Africa & 1968 & I & - & - & MI \\
\hline Plagiolepis alluaudi & Formicidae & Madagascar & 2016 & I & 2016 & I & MI \\
\hline Plagiolepis schmitzi & Formicidae & Mediterranean basin & no date & $\mathrm{O}$ & - & - & $\mathrm{TI}$ \\
\hline Tapinoma melanocephalum & Dolichoderinae & Indo-Pacific & 2002 & I & 2006 & I & MI \\
\hline Technomyrmex albipes & Dolichoderinae & Tropical Asia & 2015 & $\mathrm{O}$ & - & - & $\mathrm{TI}$ \\
\hline Technomyrmex difficilis & Dolichoderinae & Madagascar & 2015 & I & - & - & MI \\
\hline Technomyrmex vitiensis & Dolichoderinae & South-East Asia & 2014 & I & 2008 & I & MI \\
\hline Tetramorium bicarinatum & Myrmicinae & Indo-Pacific & 1918 & I & 2004 & $\mathrm{Ol}$ & MI \\
\hline Tetramorium calidum & Myrmicinae & Western Asia & no date & I & - & - & $\mathrm{TI}$ \\
\hline Tetramorium group simillimum & Myrmicinae & Africa & 1968 & I & - & - & MI \\
\hline Tetraponera allaborans & Pseudomyrmecinae & Tropical Asia & - & - & 2003 & Ol & $\mathrm{TI}$ \\
\hline
\end{tabular}


Figure 1.

(a) Lasius neglectus

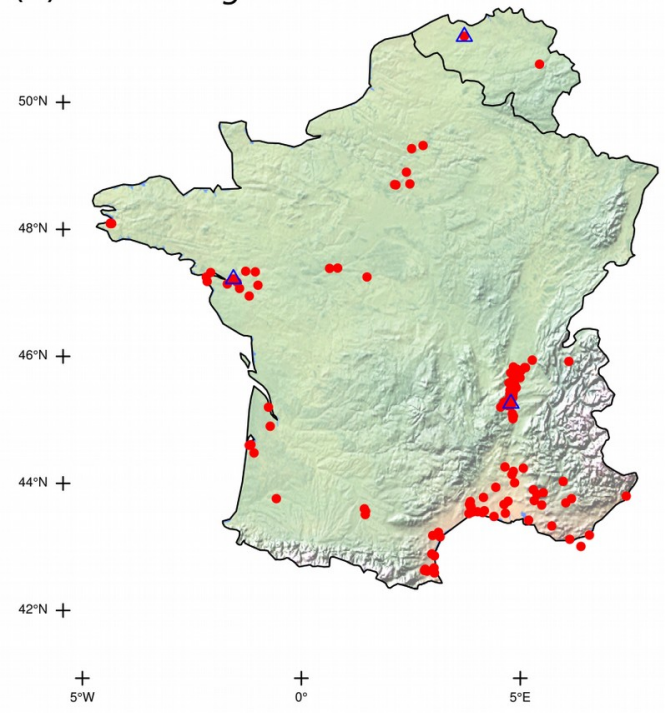

(b) Linepithema humile

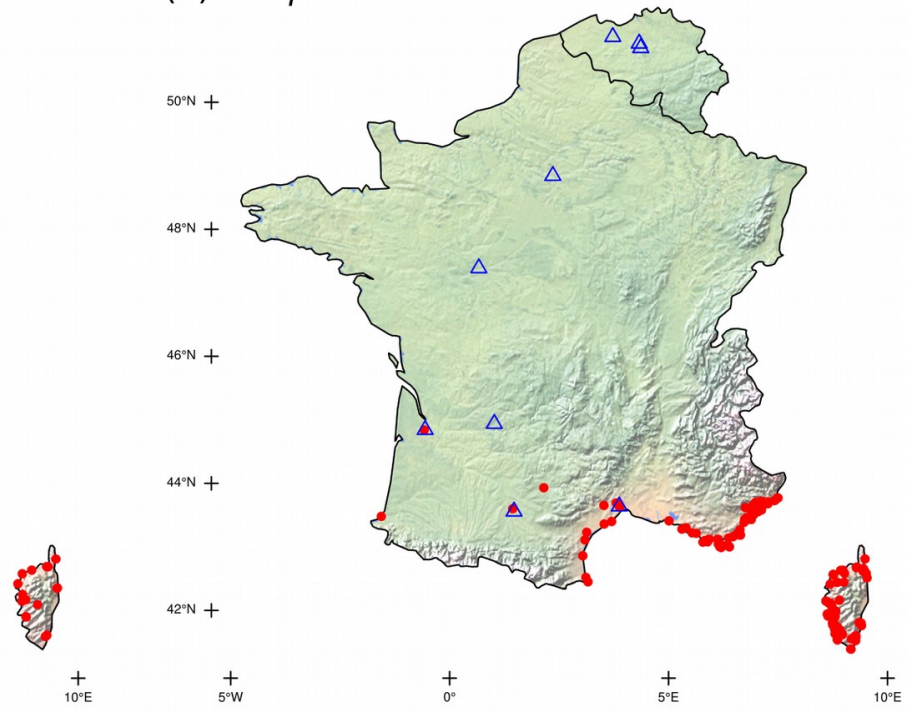

(c) Monomorium carbonarium

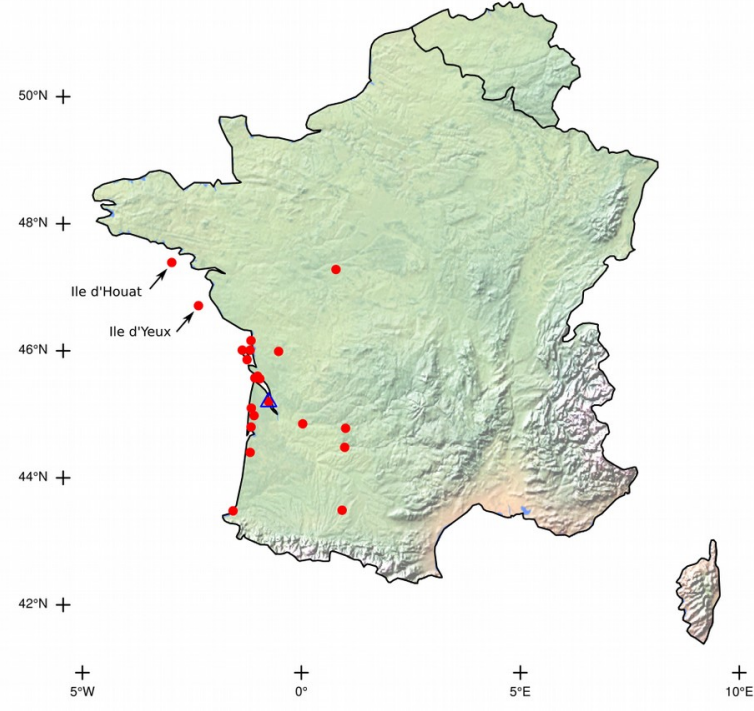


Figure 2.

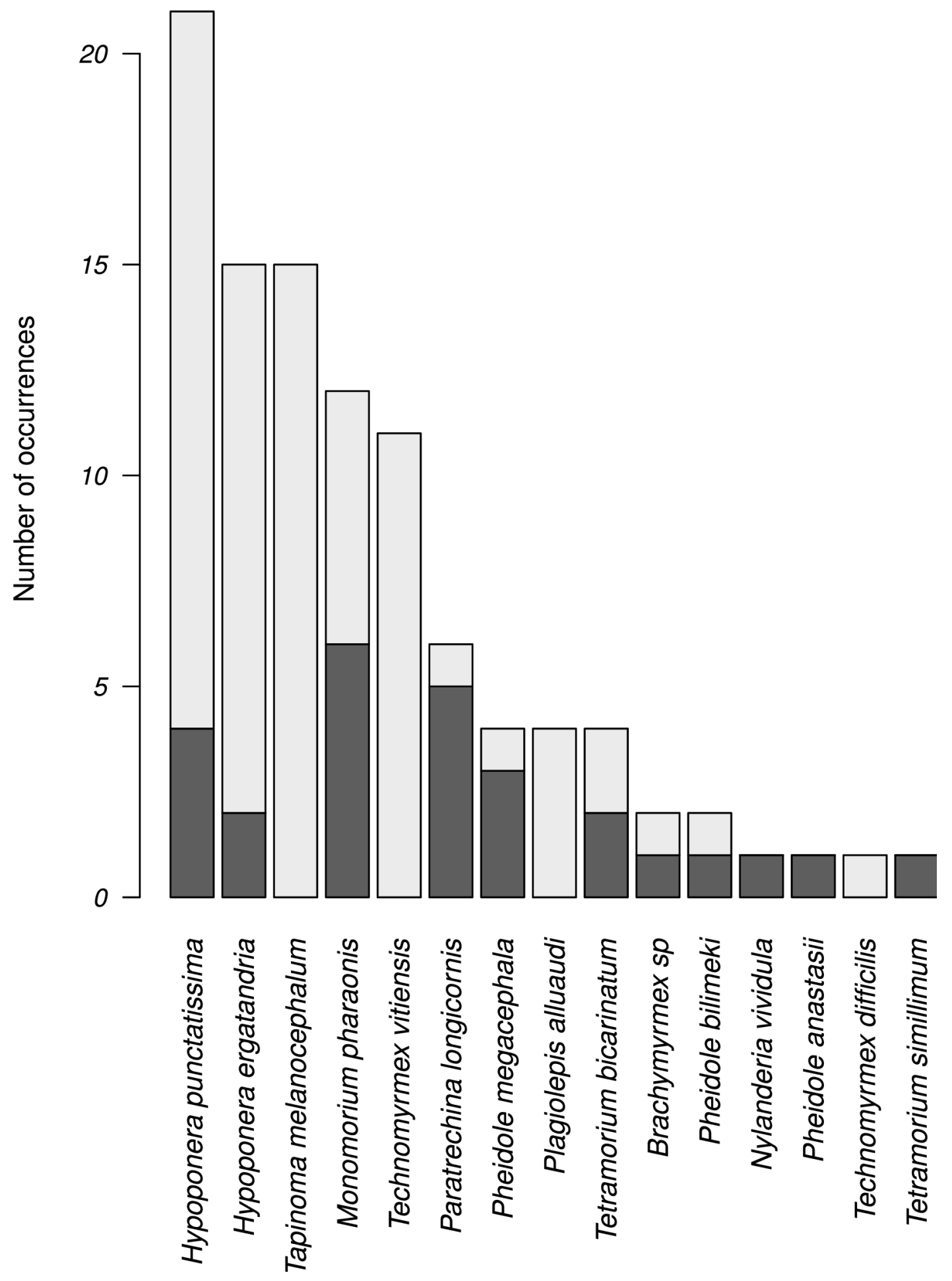


Figure 3.

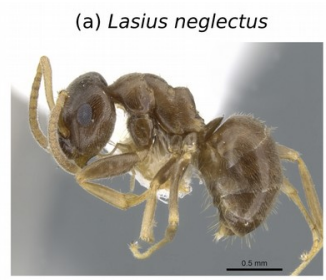

(b) Linepithema humile

(c) Monomorium carbonarium

(d) Hypoponera ergatandria
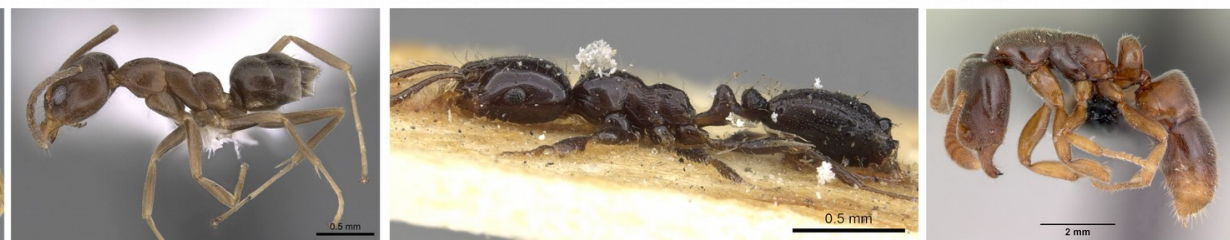

(e) Hypoponera punctatissima

(f) Monomorium pharaonis

(g) Nylanderia vividula
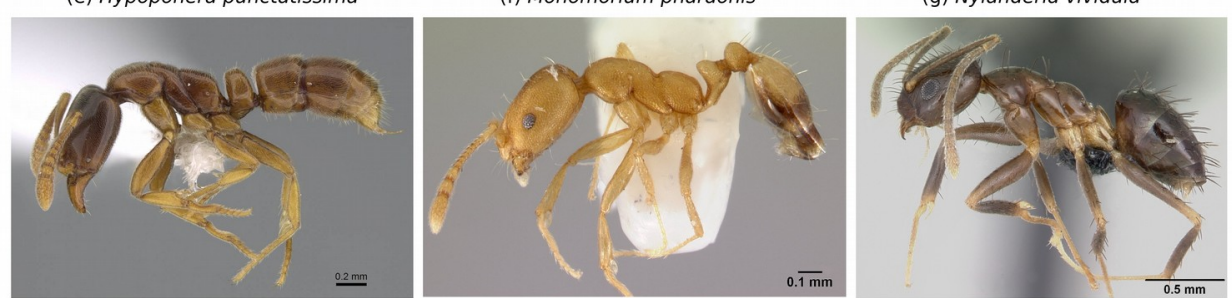

(h) Paratrechina longicornis
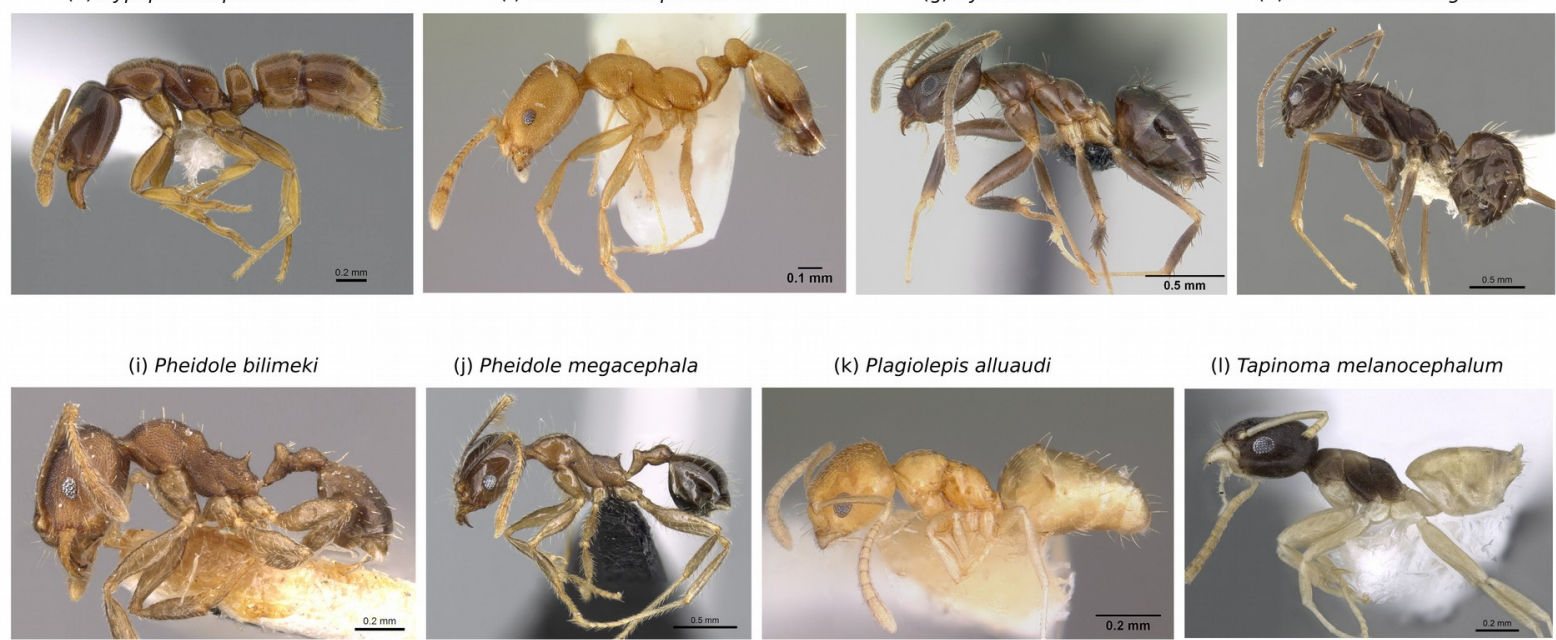

(k) Plagiolepis alluaudi

(I) Tapinoma melanocephalum
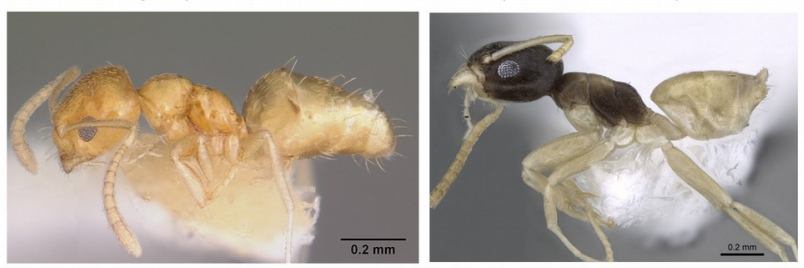

(m) Technomyrmex difficilis

(n) Technomyrmex vitiensis
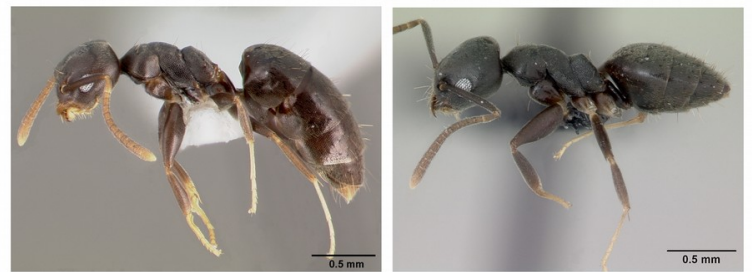

(o) Tetramorium bicarinatum

(p) Tetramorium caldarium
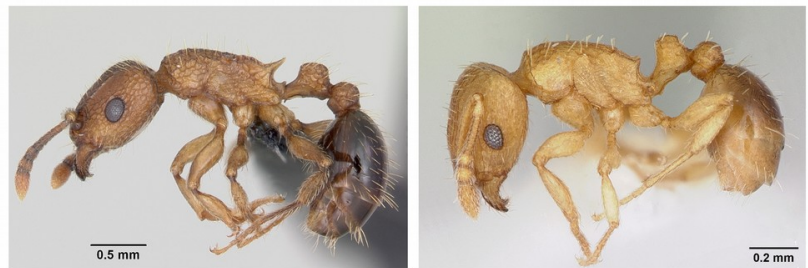
Figure 4.
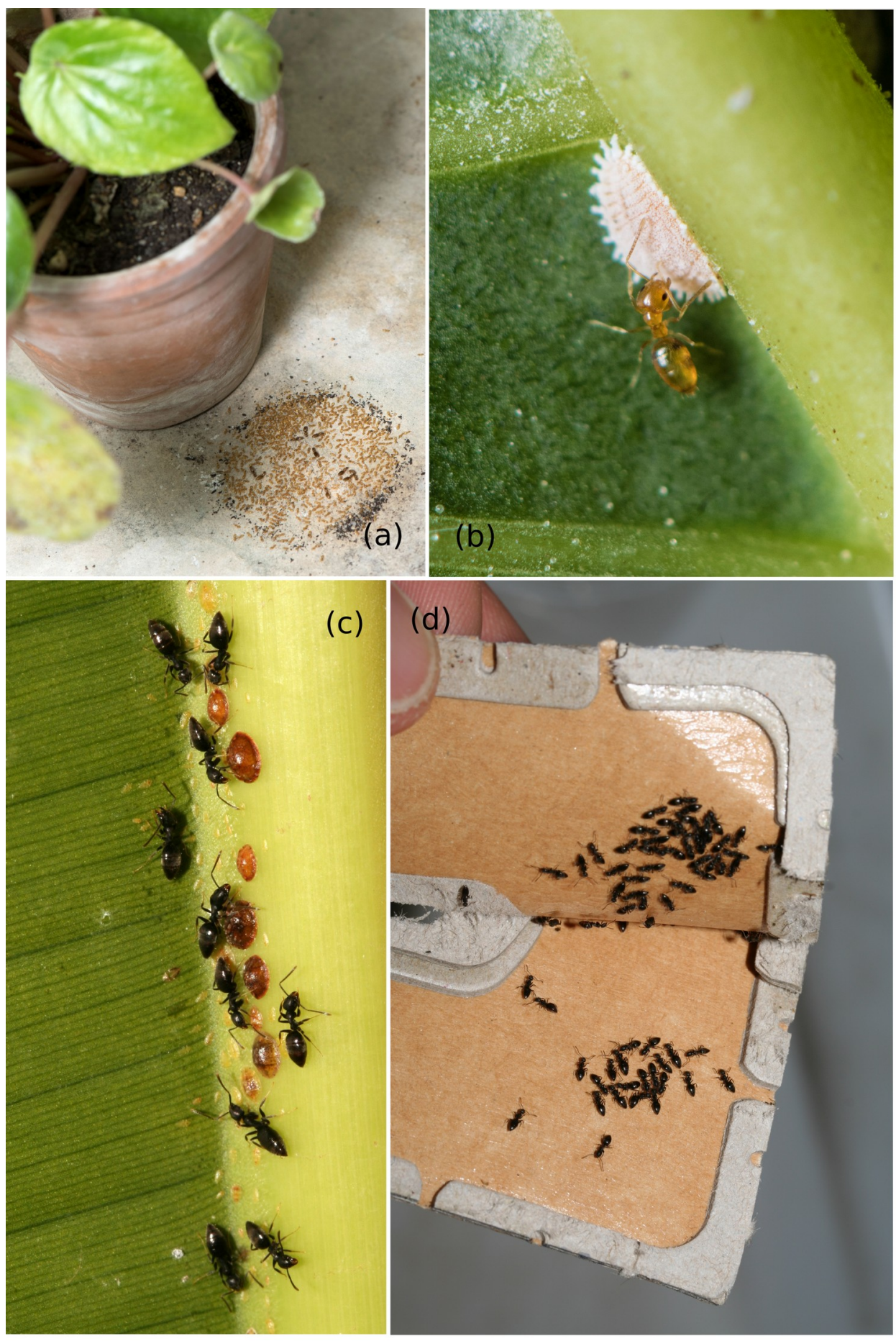